\title{
A Cytokine-based model for the pathophysiology of Long COVID symptoms
}

Russell N. Low, $\mathrm{MD}^{1}$, Ryan J. Low, $\mathrm{PhD}^{2}$, Athena Akrami, PhD ${ }^{2}$

From: 1. Sharp HealthCare and Sharp Memorial Hospital, 7901 Frost Street San Diego, CA 92123

(retired). 2. Sainsbury Wellcome Centre, University College London. 25 Howland St, Fitzrovia, London W1T 4JG, United Kingdom. Contact: rnl email: rlow52@yahoo.com

\section{Disclosures}

Conflict of interest: No conflicts exist, including honoraria, travel to conferences, consultancies, stock ownership, equity interests, or patent-licensing arrangements.

Sources of funding: This research did not receive any specific grant from funding agencies in the public, commercial, or not-for-profit sectors. 


\section{HIGHLIGHTS}

- Long COVID patients include millions of people worldwide, and persistent symptoms following COVID-19 can continue for months.

- Varied and relapsing symptoms of Long Covid can be attributed to elevated peripheral and central cytokines, generated by an abnormal immune response.

- CNS effects may be due to direct viral invasion or an indirect immune response.

- Dysregulated activation of brain microglia, due to neuroinflammation, can cause centrally mediated symptoms.

- Upregulation of the p38 MAPK pathway by SARS-Cov-2 can be a possible mechanism by which the virus increases cytokine production.

- Progression to myalgic encephalomyelitis/chronic fatigue syndrome (ME/CFS) may be possible and could involve development of autoimmunity.

\section{Summary}

Dysregulated immune-inflammatory response with elevated peripheral and central cytokines can explain Long COVID symptoms. Hyperreactive brain microglia can modulate a host of CNS-mediated symptoms.

\footnotetext{
ABSTRACT

The Long COVID group includes patients with mild-to-moderate symptoms, in whom recovery is prolonged, lasting months. Here we propose a model for the pathophysiology of the Long COVID presentation based on inflammatory cytokine cascades and the p38 MAP kinase signaling pathways that regulate cytokine production.

In this model, the SARS-CoV-2 viral infection is hypothesized to trigger a dysregulated peripheral immune system activation with subsequent cytokine release. Chronic low-grade inflammation leads to dysregulated brain microglia with an exaggerated release of central cytokines, producing neuroinflammation. Intermittent fatigue, Post Exertional Malaise (PEM), CNS symptoms with "brain fog," arthralgias, paresthesias, and GI and ophthalmic problems can all be attributed to elevated peripheral and central cytokines.
}

There are abundant similarities between symptoms in Long COVID and myalgic encephalomyelitis/chronic fatigue syndrome (ME/CFS). A post-infectious ME/CFS model 
involving a dysfunctional peripheral and central cytokine inflammatory response and autoimmunity is emerging. DNA polymorphisms and viral-induced epigenetic changes to cytokine gene expression may lead to chronic inflammation in Long COVID patients, predisposing some to develop autoimmunity, which may be the gateway to ME/CFS.

Keywords: COVID-19, Cytokines, Long COVID, Long Hauler, Neuroinflammation

\section{Introduction}

The COVID-19 Prolonged Symptoms Survey - Analysis Report of May 11, 2020, described 640 patients with a protracted clinical course greater than two weeks [5]. The report shows that, among the participants, the chance of full recovery by day 50 is less than $20 \%$. Patients suffer from a plethora of symptoms, impacting their quality of life and ability to work. The top ten reported symptoms include shortness of breath, chest tightness, mild-to-moderate fatigue, chills or sweats, body aches, dry cough, fever $\left(98.8-100^{\circ} \mathrm{F}, 37.2-37.8^{\circ} \mathrm{C}\right)$, headache, and cognitive/concentration challenges termed "brain fog" [5]. Many Long COVID patients report that their symptoms are markedly exacerbated by physical exercise or mental stress/exertion. The exertion precipitates a "storm" of recurrent symptoms, with the onset measured in days following the activity.

This previously unrecognized and under-reported group of patients has grown within various social media support groups. The Body Politic COVID-19 Support Group now records over 8,000 members, and the Long Covid Support Group on Facebook has more than 30,000 members. These patients have been dubbed the "Long-Hauler," or "Long COVID" group. The actual number of people worldwide struggling with prolonged recovery from COVID-19 has not been measured systematically. However, the current estimates suggest between $10 \%$ and $40 \%$ of people infected with COVID-19 have prolonged symptoms [20,36,62,223]. Among the hospitalized population, an even larger number (up to $90 \%$ ) can suffer from symptoms 8-12 weeks after admission $[4,28,86]$.

Questions persist about the pathophysiology of their symptoms and their eventual outcome. Analyzing the pattern of symptoms, in terms of the underlying pathophysiology on cellular and macromolecular levels, will shed light on the Long COVID patients' clinical plight. Our analysis demonstrates how all of these conditions can be related to pro-inflammatory cytokines.

Viral infections incite a pro-inflammatory response with increased production of cytokines and chemokines $[158,184]$. Cytokines are small proteins involved in cell signaling. They are secreted by numerous cell types, including endothelial cells, macrophages, monocytes, and lymphocytes, and can act in an autocrine, paracrine or endocrine manner. Cytokines can be broadly 
categorized into different families, including interferons, interleukins, colony-stimulating factors, and tumor necrosis factors [40]. Chemokines recruit inflammatory cells as part of the normal immune response [40].

Several studies have shown that both mild and severe cases of COVID-19 can result in a hyper-inflammatory response characterized by elevated levels of numerous cytokines, including IL-6, IL-8 and TNF- $\alpha$ [103] [59][250]. While these proinflammatory cytokines are expected to be induced upon viral infection, SARS-CoV-2 encodes several proteins that specifically evade initial type I interferon response [94,129], resulting in a prolonged and, in certain cases, dysregulated cytokine response. However, COVID-19 is a heterogeneous disease and not all the pieces of the puzzle are in place. A recent report describes cases in which elevation of cytokine IL-6 in severe COVID19 patients is not observed to be as high as in Acute Respiratory Distress Syndrome (ARDS), sepsis or Cytokine Release Syndrome Grade 3 [204].

It has been suggested that approximately $80 \%$ of COVID-19 patients have mild disease, while $15 \%$ suffer severe infections, requiring oxygen, and $5 \%$ are critical infections, requiring ventilation [30]. An abnormal immunologic response to the virus results in an uncontrolled systemic inflammatory response with more severe infections [30]. This condition, known as the "Cytokine Storm," has gained widespread attention as the mechanism through which severely ill patients with COVID-19 pneumonia show a progression of symptoms [59]. Acute Respiratory Distress Syndrome (ARDS), requiring mechanical ventilation and ICU admission, results in a mortality rate approaching $40 \%-50 \%$ in COVID-19 patients $[150,236]$. Uncontrolled overproduction of pro-inflammatory cytokines and chemokines produces the cytokine storm, resulting in systemic inflammation, ARDS, and multiple organ failure $[40,98,225,243]$.

The binary description of COVID-19 patients, in which one either recovers in 1-2 weeks (80\% of patients according to [30] or progresses to a cytokine storm with ICU admission (the remaining $20 \%$ in [30]), ignores the third group, who experience chronic, relapsing symptoms that may persist for several months. The Long COVID patients are not included in or explained by the original description of COVID-19 patients. We believe this third group deserves attention from the medical and scientific community.

\section{THE CYTOKINE RELEASE SYNDROME}

While the focus on the "cytokine storm" is clinically relevant in the severely ill COVID-19 patients, the term ignores the role cytokines can play in the symptoms of less severe disease, including those of Long COVID patients.

Instead, we believe that the Cytokine Release Syndrome (CRS) description provides a more balanced presentation of the spectrum of symptoms in patients with clinical manifestations of 
elevated cytokine production $[128,201]$. CRS is a systemic inflammatory response triggered by infections, drugs, antibody-based immunotherapies, chemotherapeutic agents, and graft-vs-host disease (both acute and chronic) [201] [Figure 1].

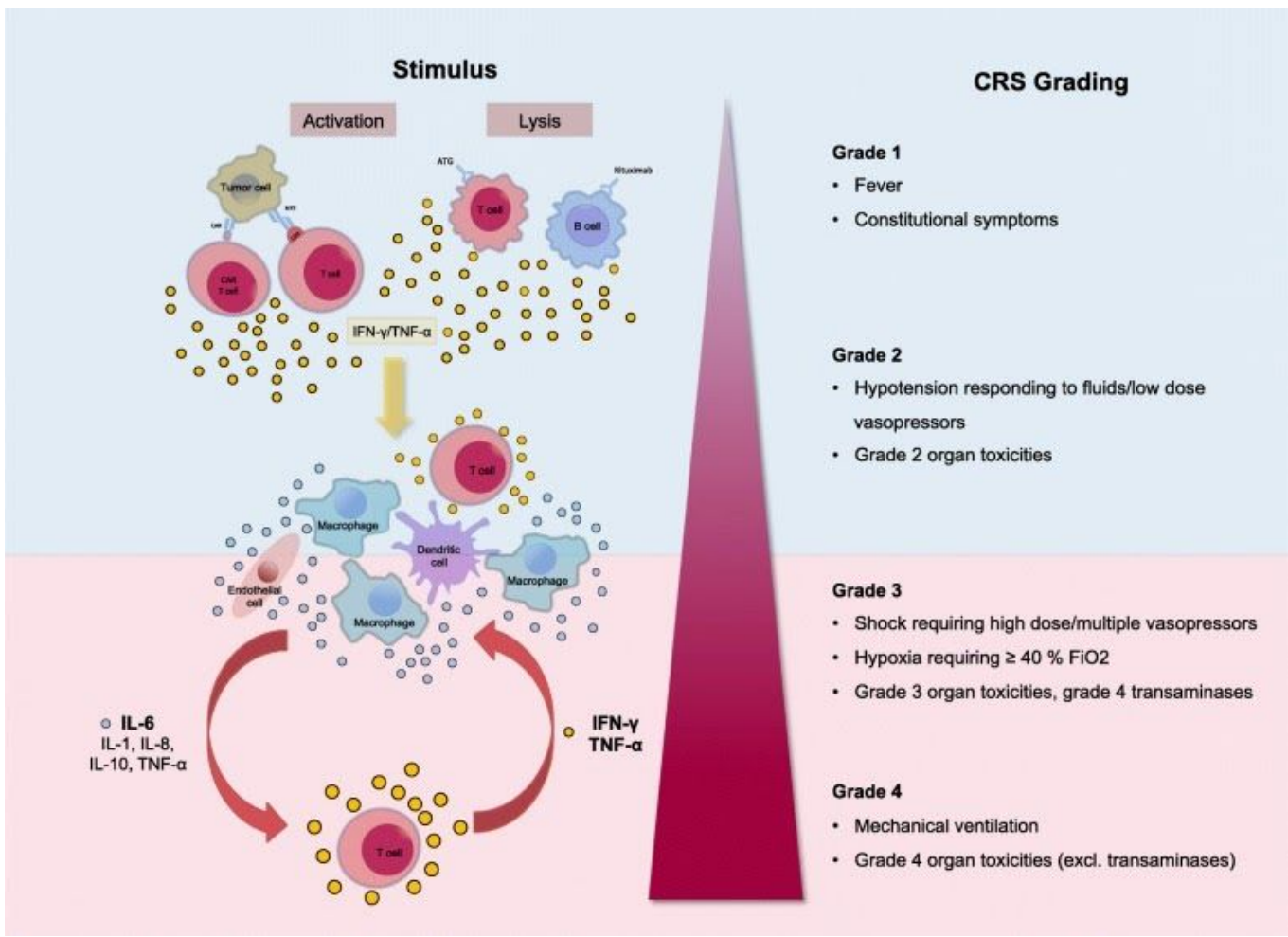

Figure 1. Grading of the Cytokine Release Syndrome. Activation of T cells induces a release of IFN- $\gamma$ or TNF- $\alpha$. This process activates macrophages and other immune cells, releasing proinflammatory cytokines. Large amounts of IL-6 are released, which in a positive feedback loop activates $T$ cells and other immune cells leading to a cytokine storm. CRS Shimabukuro-Vornhagen (http://creativecommons.org/licenses/by/4.0/)

Clinical presentation ranges from mild flu-like symptoms to life-threatening "cytokine storm." The CRS grading system includes Grade 1 with fever and mild constitutional symptoms, Grade 2 with hypotension responding to fluids and vasopressors, Grade 3 with shock, hypoxia, and Grade 4 with respiratory failure and ARDS requiring mechanical ventilation, disseminated intravascular coagulation $[161,201]$. CRS is a multiorgan process affecting the lungs, CNS, spleen, gastrointestinal tract, kidneys, hepatobiliary tree, heart, musculoskeletal system, white cells, and platelets.

In general, Grade 1 CRS with fever, fatigue, headache, rash arthralgia, and myalgia correlates with the symptoms of long COVID patients (see the section Long COVID Symptoms and Cytokine Release Syndrome Model). As with the more severe CRS grades, Grade 1 symptoms 
result from proinflammatory cytokine release from activated macrophages and white cells, initiating the inflammatory cascade.

These cytokines and chemokines recruit immune cells [45], which then secrete cytokines producing a positive feedback loop. While this process occurs in the body's normal inflammatory response, in the CRS, loss of regulation of the inflammatory cascade can result in an uncontrolled destructive process $[40,151]$. The cytokine cascade's autoimmune inflammatory effect can be responsible for more damage than is produced directly by the SARS-CoV-2 virus [245].

There are critical inter-individual differences in the cytokine pathway. The COVID-19 comorbidities are characterized by low-grade inflammation and elevated cytokine levels [138]. For example, aging [149], obesity [185], diabetes mellitus [187,239], and hypertension [219] are associated with increased proinflammatory cytokines and a worse COVID-19 prognosis [177].

\section{LONG-COVID SYMPTOMS AND CYTOKINE RELEASE SYNDROME MODEL}

With this knowledge of the effects of cytokines in COVID-19 patients, how can one explain the varied and relapsing symptoms of Long COVID patients? This section will briefly review the evidence linking elevated cytokines to various symptoms commonly experienced in Long COVID patients.

\section{A Model for CNS Mediated Symptoms}

Many Long Covid symptoms are centrally mediated by the brain, including generalized symptoms such as fatigue, malaise, fever, and dyspnea [240], as well as cognitive and neurological symptoms such as "brain fog," concentration difficulty, memory loss, dizziness, and problems with balance $[5,25,62]$. Viral-induced CNS changes can explain the persistent and relapsing course of these symptoms in Long COVID. We describe two pathways that could produce such changes (Fig. 2): (1) neuroinflammation, triggered by direct CNS infection or signals from the peripheral immune system, and (2) modulation of CNS function by a persistently activated peripheral immune system. 


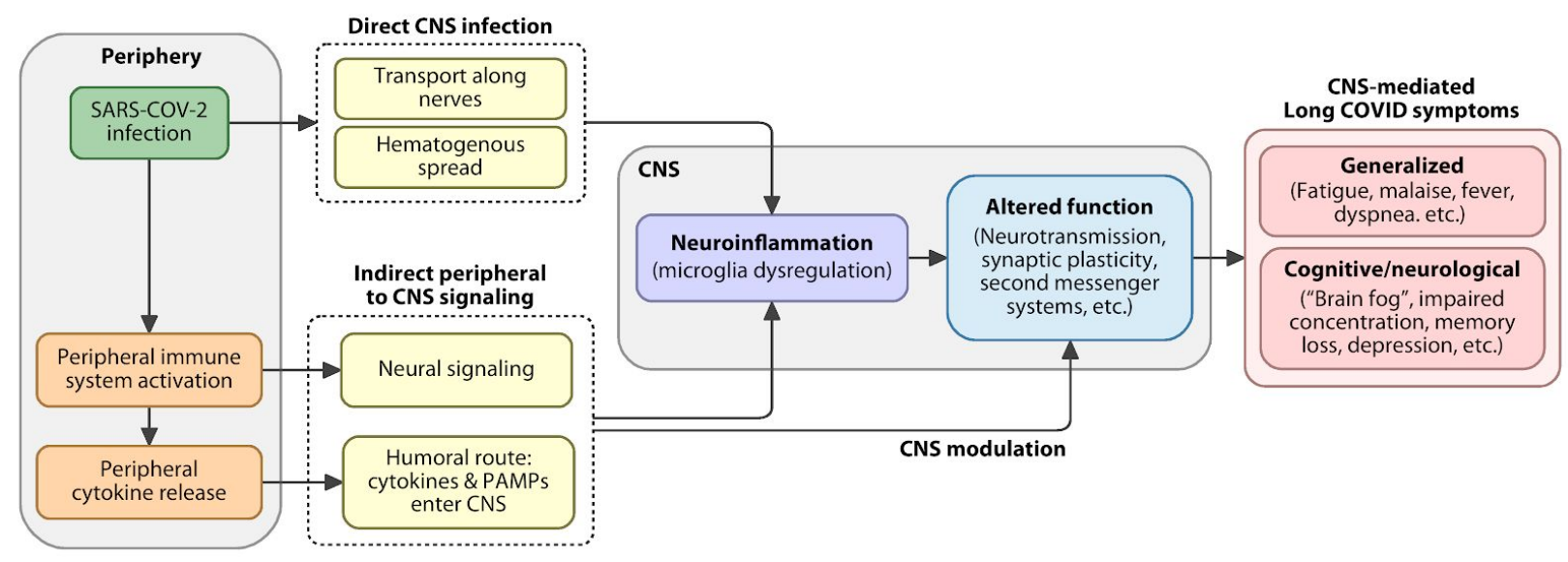

Figure 2. Proposed model of pathophysiology underlying direct and indirect CNS-mediated Long Covid symptoms.

Direct Viral Invasion of the CNS - SARS-CoV-2 is neuroinvasive, neurotropic, and neurovirulent [132]. Viral proteins have been found in the brainstem and cranial nerves in autopsies [145]. The route of SARS-CoV-2 entry into the CNS is currently unknown, but could include: (1) Transport along cranial and peripheral motor, sensory, or autonomic nerves (e.g. olfactory to CNS invasion) $[22,132,179]$. Here, the virus invades nerve endings and is actively transported within neurons to the brain. (2) Alternatively, hematogenous spread could occur, in which the virus passes from alveolar epithelial cells or endothelial cells of other organs into the blood circulation [132]. The virus penetrates the Blood Brain Barrier (BBB) through points of weakness (e.g. circumventricular organs and the choroid plexus), or by damaging the vascular endothelium of the BBB, resulting in neuroinvasion [132,179]. Neuroinvasion can trigger neuroinflammation, thereby altering CNS function and producing Long Covid symptoms, as discussed below [Figure2].

Indirect Immune-Mediated Viral Effects on the CNS - While direct CNS viral infection is possible, indirect CNS involvement through a viral-mediated immune response is equally likely $[145,159]$. As part of the innate immune response, proinflammatory cytokines are released by activated peripheral immune cells in response to pathogen-associated molecular patterns (PAMPS) detected by pattern-recognition receptors (PRRs). Peripherally released cytokines act on the brain via two pathways of communication: (1) a neural route via primary afferent neurons, including the vagus nerve, innervating the site of the infection; (2) a humoral route, in which peripheral cytokines or PAMPS cross the BBB at the circumventricular organs and choroid plexus and stimulate the production of proinflammatory cytokines by brain immune cells $[52,53]$. As discussed below, these signals from the peripheral immune system to the CNS could lead to Long Covid symptoms by triggering neuroinflammation and/or by directly and persistently modulating CNS function [Figure 2]. 


\section{Neuroinflammation and Microglial Cell Dysregulation}

Direct or indirect viral effects on the CNS can trigger neuroinflammation-a chronic immune response within the brain involving long-term activation of microglia, the local release of inflammatory cytokines, and resulting oxidative stress [200,213]. Neuroinflammation has been implicated in the pathogenesis of many neurodegenerative [81] and psychiatric diseases [170], and can also be triggered by viral infection [213]. In a recent study, pronounced neuroinflammatory changes were found in the brainstem of post-mortem brain autopsies in COVID-19 patients [145]. In these patients, evidence of SARS-CoV-2 viral proteins was found in over half of patients in the brainstem and cranial nerves. However, neuropathological changes were not associated with the presence of the virus. Instead, the CNS damage and neurological manifestations [134] were attributed to cytokine-mediated neuroimmune stimulation, also indicated by the presence of neuroinflammation in the ocular vitreous cavity of persons who recovered from COVID-19 [10].

Glial cells, such as astrocytes and microglia, play an essential role in brain neuroinflammatory insults [29]. Microglia, the resident brain macrophages, acquire different functional phenotypes in response to their environment, alternating between a quiescent reparative $\mathrm{M} 2$ state (anti-inflammatory) and an activated proinflammatory M1 state [113,251] [Figure 3].

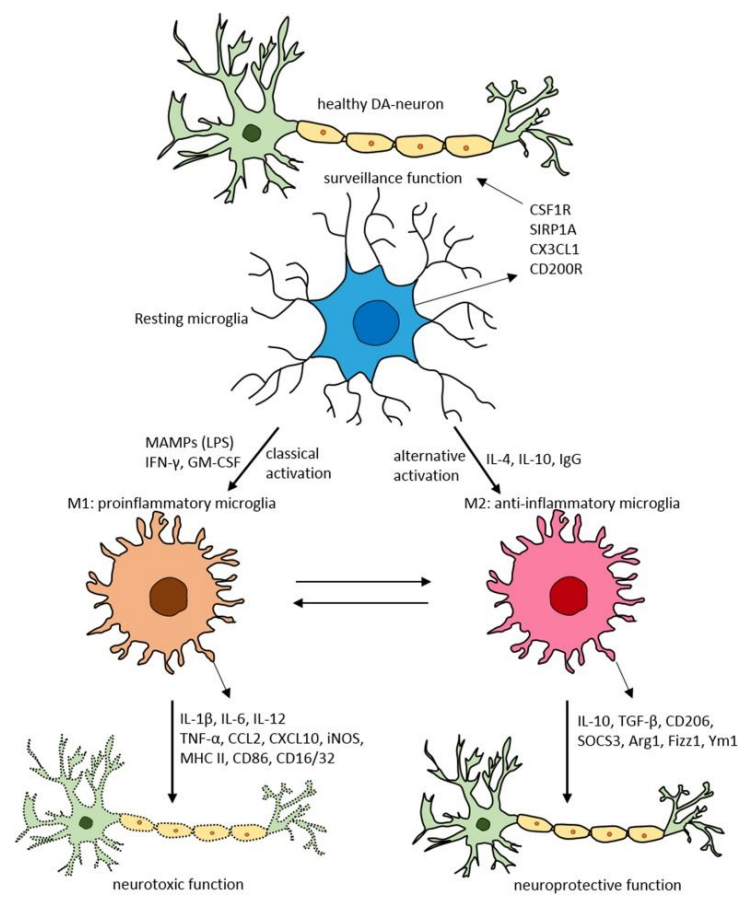

Figure 3. Schematic of microglial polarization states and functions.[215] (http://creativecommons.org/licenses/by/4.0/) 
Usually, the system is well regulated. However, with aging, chronic infection, or stress, microglia can become dysfunctional $[16,131]$. These dysregulated microglia are hyperreactive to signals from the peripheral immune system, producing an exaggerated and prolonged central cytokine response to an otherwise mild immune challenge $[90,183]$. The primed microglia then become resistant to normal regulation, failing to revert to the quiescent state after inflammation resolution [173]. The dysregulation of microglia has been implicated in the pathophysiology of numerous neurodegenerative disorders [222]. A study of two non-neurotropic strains of the H1N1 influenza virus showed neuroinflammation from cytokine release by activated and primed hippocampal microglial cells [12]. Long-term neuroinflammation persisted beyond the resolution of the acute viral infection [101].

\section{Cytokine modulation of the CNS}

In addition to neuroinflammation, circulating cytokines can modulate systemic functions by direct action on the brain $[47,137]$. This modulation is known to occur in response to viral infection. For example, even non-neurotropic viruses that do not invade the brain can cause CNS effects, triggered by a peripheral immune response [12]. Human and animal studies have shown that increases in circulating cytokines can induce typical "sickness behaviors" $[50,102,137,246]$, including decreases in general activity, exploratory behavior, social and sexual interaction, food and water intake, and preference for sweets (anhedonic behavior), as well as altered sleep and impaired learning. Injection of IL-1ra (an inhibitor of pro-inflammatory IL-1) can suppress hypothalamic-pituitary-adrenal (HPA) axis activation and the associated sickness behaviors (sleep and behavioral changes) that were induced by systemic administration of an endotoxin [46].

Evidence shows that cytokines (e.g. IL-1 $\beta$, IL-6, and TNF- $\alpha$ ) play a role in complex cognitive processes via neuromodulation [70,116], second messenger systems in neurons $[155,172]$, neurogenesis [70], and modification of synaptic plasticity [116]. Cytokines can also induce pyrogenic responses in the brain by the synthesis of prostaglandins [120], and can additionally influence many neuroendocrine systems, the most prominent of which is the HPA-axis $[120,192]$. Cytokines can also influence the synthesis, secretion, and reuptake of many central neurotransmitters, including noradrenaline, dopamine, glutamate, serotonin, GABA, and acetylcholine, as well as the expression of several neuropeptides in different brain areas $[71,120,192,218]$. The alterations in neurotransmission may lead to depression, anxiety, and mental sluggishness or "brain fog" [11,153]. Overexpression of cytokines has been associated with neuropsychiatric disorders such as depression [27,54,122].

In summary, a peripheral inflammatory response may lead to cytokine release and mobilization of immune cells, both of which have CNS effects $[153,167]$. SARS-CoV-2 can affect the CNS via 
proinflammatory cytokines, producing neurological symptoms [167]. Such "sickness behavior" usually resolves once the acute illness terminates. However, subsequent neuroinflammation and oxidative stress can produce prolonged sickness behavior, cognitive deficits, and increased sensitization to intrinsic and extrinsic stress [90]. In Long COVID, dysregulation and chronic activation of cytokine signaling, as discussed later, can cause prolonged CNS effects. This model of dysregulated, activated, and primed brain cells and microglia, responding to peripheral or central cytokines, can explain the chronic and relapsing clinical course of many Long COVID symptoms.

\section{Mild Constitutional Symptoms}

The constitutional symptoms of fever, chills, headache, arthralgia, and mild dyspnea can be attributed to cytokine release $[95,201]$. These symptoms of "sickness behavior" are mediated by the brain which recognizes proinflammatory cytokines as signals of sickness (see CNS Mediated Symptoms). The peripheral innate immune response to pathogen-associated molecular patterns (PAMPS) produces cytokines (IL-1, IL-6, and TNF-a) [51]. Most of these proinflammatory cytokines are pyrogenic (IL-6, IL-1, IFN-y, and TNF-a. TNF-a can have both pyrogenic and antipyretic properties) and their systemic circulation can induce febrile response $[39,75,171]$.

\section{Neuropathic Pain}

Paresthesia reported in Long COVID patients can be related to cytokines. In patients with diabetic neuropathy, neuropathic pain correlated with increased levels of IL-6 and IL-10 for large nerve fiber damage [139]. Patients with polyneuropathies show elevated serum cytokines IL-8, TNF and lower expression of IL-10 [125]. Disease duration positively correlates with IL-6 gene expression [125].

Post-infectious neuropathies are precipitated by an autoimmune process in which antibodies to the infectious agent cross-react with peripheral nerve myelin [68]. Like other neuropathies, the process is directly related to cytokines [37], which are also a therapeutic target [105].

\section{Extreme Fatigue}

Post-viral fatigue is well described [108]. Extreme physical fatigue can have two components, actual "muscle fatigue" and "central fatigue," related to abnormalities in deep brain circuits 
involved in motor planning and execution [232]. For ME/CFS patients and perhaps for Long COVID patients, the fatigue can originate centrally with decreased basal ganglia function, including psychomotor slowing [31,154]. With chronic inflammation, cytokines target the basal ganglia and dopamine function, producing persistent fatigue [109].

Cytokines cause neurotransmitter release in the brain, including serotonin, producing extreme central fatigue [41]. In healthy patients, the administration of IL-6 and IL-1 $\beta$ produces fatigue, as well as sleep disturbances, and difficulty concentrating [211]. In people with post-infection fatigue recovering from West Nile virus, elevated levels of both proinflammatory and antiviral cytokines (IL-2, IL-6, IFN- $\gamma$, IP-10, among others) were detected [108]. In patients with rheumatoid arthritis and systemic lupus erythematosus, fatigue improved with anti-IL-6 medications [42,234]. Viral-induced mitochondrial dysfunction leads to decreased ATP and increased cytokines IL-1 $\beta$ and IL-18 through activation of inflammasomes [88,195]. A similar mechanism can be at play in COVID19, where mitochondrial hijacking by SARS-COV-2 is suggested $[194,203]$.

\section{Post-exertional Malaise}

Severe post-exercise fatigue and malaise (PEM), is one of the most striking and demoralizing symptoms reported by many of the Long COVID patients. One to two days after a mild-moderate exercise session, Long COVID patients experience marked worsening of symptoms with extreme fatigue, malaise, fever, shortness of breath, and neurological deficits.

Dysfunctional mitochondria can partially mediate PEM in muscles and brain microglia with less efficient glycolysis. Subsequent lactic acidosis with increasing ROS, and elevated cytokines results in exercise-induced peripheral and central fatigue $[156,164]$.

For decades, exercise physiologists have known that exercise induces cytokine release [114]. Suzuki described a 2-15-fold increase in serum cytokines following maximal exercise [217]. Following a marathon race, serum IL-6 levels increased 100-fold [217]. Modest increases of IL-6 are expected after exercise of low-to-moderate intensity or intermittent physical activity of a shorter duration [58]. Thirty minutes of acute exercise resulted in a $165 \%$ rise in IL-6 and a 32\% rise in IL-8 in endurance-trained and sedentary young men [124]. 
The magnitude of the exercise-induced IL-6 response is dependent on the intensity and especially the duration of the exercise, while the mode of exercise has little effect [77]. Plasma IL-6 peak occurs as soon as the activity ends, returning to baseline after a few hours of recovery $[78,114]$. The exercise-induced cytokine release was more marked in the evening compared to the morning [118].

We argue that for the COVID-19 patients, the exercise-induced cytokines may trigger a recurrence of symptoms by reinitiating the same feedback loop pathways that caused the initial symptoms. Essentially, symptoms can all be due to peripheral and central cytokine cascades.

\section{Psychological Stress Precipitates Cytokine Release}

Intense mental concentration precipitates a recurrence or worsening of symptoms in Long COVID patients identical to physical stress. It is known that social, psychological, or mental stress is also associated with cytokine release [76]. A meta-analysis of 34 studies found increases in circulating IL-6, IL-1 $\beta, \mathrm{IL}-10$, and TNF- $\alpha$ and stimulated IL- $1 \beta$, IL-4, and interferon $\gamma$ in response to acute psychological stress [143]. The peak IL-6 level was at 90 minutes post-stress with a $>6$-fold increase over baseline.

\section{The Onset of Symptoms Post Exertion}

The delay in onset of symptoms following physical or mental stress is also predictable because the cytokines do not cause the symptoms; they just start the process of immune system recruitment and activation that leads to the symptoms. Cancer immunotherapy drugs produce the CRS with an onset of symptoms within a few days of the drug administration [201]. This timing correlates with the delayed onset of Long COVID symptoms after exercise.

\section{Gastrointestinal Tract Symptoms}

Ten percent (2-50\%) of COVID-19 patients report diarrhea, sometimes alternating with constipation [49]. SARS-Cov-2 is present in feces in $55 \%$ of patients $[231,238]$. Wang et al. reported a 25 -day median duration of fecal viral shedding with only $25 \%$ reporting diarrhea and $1 \%$ with nausea and vomiting. No significant differences were observed in GI symptoms between patients with positive and negative fecal viral tests [231].

The GI symptoms in Long COVID patients are more likely due to cytokines $[85,196]$ and associated cytokine-linked changes in the gut microbiome $[85,196]$. Diarrhea in systemic infections without intrinsic GI tract disease is well known. Pathogenesis may be related to 
cytokines, including IFN-y, IL-6, and IL-10 [189]. In patients with irritable bowel syndrome, pro-inflammatory cytokines, IL-6, and TNF-a, are elevated [186].

\section{Arthralgia}

Arthralgia has been described in $15 \%$ of coronavirus patients [197]. Rheumatologists have noted that the pattern of elevated pro-inflammatory cytokines in COVID-19 are similar to those in patients with rheumatoid arthritis [197].

\section{Ophthalmic Problems}

Ophthalmic manifestations of COVID-19 reported in hospitalized patients, include conjunctival hyperemia, and chemosis, epiphora, and increased secretions [80,237]. Ocular mast cells produce the inflammatory cytokines resulting in conjunctival hyperemia and chemosis [35]. Visual and ocular disturbances in Long COVID patients may be similar to those reported in $\mathrm{ME} / \mathrm{CFS}$, including blurred vision, difficulty focusing, difficulty tracking lines of print, diplopia, light intolerance, and problems with peripheral vision [9]. Evidence of inflammatory cells in the vitreous cavity have been found in patients recovered from COVID-19 [10]. Cytokine-induced brainstem neuroinflammation could produce some of these visual problems.

\section{Thrombotic Complications of COVID-19: Relationship to Cytokines}

The prothrombotic complications of SARS-CoV-2 became evident with reports of small vessel cerebral infarctions in young patients [119]. Autopsies described the lungs and other organs full of micro clots [235]. Myocardial infarctions, deep vein thrombosis, and systemic arterial emboli describe a systemic thrombotic process initiated by the SARS-CoV-2 virus. In a recent study, $31 \%$ of 184 COVID-19 ICU patients had thrombotic complications [119].

The pathophysiology of thrombosis may involve direct vessel endothelial injury by the SARS-CoV-2 binding to the ACE2 receptor [38]. Also, pro-inflammatory cytokines increase blood viscosity $[112,148,233]$, and specific cytokines, including interferon- $\gamma$, IL-6, chemokine-ligand-2, IL-17A, IL-9, IL-1 $\beta$, and growth-factor, have a prothrombotic effect [169].

SARS-Cov-2 binds to platelet ACE2 receptors, leading to hyperactivation and platelet aggregation [249]. Spike protein directly stimulates platelets to facilitate the release of coagulation factors and the secretion of inflammatory cytokines [249]. In turn, cytokines and erythropoietin potentiate platelet maturation. Platelet-producing megakaryocytes are found in unusual anatomic locations at autopsy of COVID-19 patients [13]. SARS-CoV-2 induces gene expression leading to platelet hyperreactivity, contributing to COVID-19 pathophysiology 
[141]. Critical interactions between inflammatory and thrombosis pathways, leading to SARS-CoV-2 induced vascular disease have been recently confirmed in rhesus macaques, in which disruption of endothelial cells via cytokine was observed [1].

\section{Orthostatic Tachycardia - Autonomic Nervous System Dysfunction}

Some "Long COVID" patients report postural orthostatic tachycardia (POTS) tachycardia [69]. POTS is dysautonomia characterized by tachycardia within 10 minutes of standing up. (>30 bpm increase from a supine position or $>120 \mathrm{bpm}$ in the erect position [6].

Dysautonomia is an autonomic nervous system (ANS) dysfunction, resulting in failure or overactivity of the ANS. An interplay between the ANS and the immune system involves cytokines. Cytokines modulate the activity level of the sympathetic and parasympathetic nervous systems, innervating multiple organs [115]. POTS syndrome is explained by a sympathetic nervous system dysfunction, associated with increased IL- 6 levels but not C-reactive protein [174].

\section{Loss of Regulation of Cytokine Pathways in Long COVID patients}

Essentially, the question is, why are clinical symptoms of the "Long COVID patients" so long-lasting? Their protracted clinical course could reflect impaired viral clearance with a reservoir of undetected viruses [7,83]. Residual viral fragments could be inciting inflammation. However, it is unlikely that patients are still infected with viable SAR-CoV-2, several months after infection. Alternatively, viral reinfection could be occurring. However, acquired immunity should limit reinfection, and there are only sporadic reports of reinfection.

For the Long COVID patients, it is more likely that the virus has been cleared and that the ongoing relapsing symptoms represent a continuing exaggerated response to cytokine release [152]. Indeed, all of the reported Long COVID symptoms can be directly attributed to cytokines. These patients exhibit an exaggerated response to the ongoing release of cytokines, which is key to understanding their disease's pathophysiology.

The normal cytokine signaling pathways include multiple checkpoint regulation sites with feedback inhibition, allowing for a return to a quiescent, non-inflamed state. Dysregulation and chronic activation of cytokine signaling can lead to immunopathology with autoinflammatory or autoimmune diseases [48]. Dysregulation of cytokine inflammation may be occurring on a system or cellular level.

\section{System-Level Dysregulation of Cytokine Expression}


Bidirectional communication between the peripheral immune system and the hypothalamic-pituitary-adrenal axis (HPA) modulates the inflammatory response. Cytokines cross the blood-brain barrier and activate the HPA axis, resulting in increased glucocorticoid secretion by the adrenal gland. Glucocorticoids, in turn, negatively feedbacks onto immune cells and inhibits the expression of proinflammatory cytokines and increases anti-inflammatory cytokines, protecting the host from detrimental consequences of an overactive immune response. Impairments in HPA axis activity and associated hypocortisolism can result in chronic inflammatory or autoimmune diseases [17,142,202,205].

Notably, 39\% of SARS survivors demonstrated transient hypocortisolism, developing several weeks after symptom onset and usually resolving by one year [130]. Proposed mechanisms include hypophysitis, direct hypothalamic involvement with binding to ACE2 receptors, and mimicry with host antibodies directed against ACTH [205]. Autopsy also showed adrenal gland necrosis [178]. While intriguing, there is no correlation between SARS survivors with hypocortisolism and those who experience chronic fatigue.

\section{Cellular Level Dysregulation of Cytokine Gene Expression}

(P38 MAPK controlling pathway, Polymorphisms, Transcription factors, and Epigenetics)

On a cellular level, viruses can induce cytokine dysregulation through several mechanisms, including viral-induced epigenetic changes in gene expression, transcription factors, and underlying gene polymorphisms. If cytokines are responsible for the myriad of chronic relapsing symptoms of the Long COVID patients, it is essential to understand the cellular controlling mechanisms that initiate or suppress cytokine release. Multiple signal transduction pathways control cytokine gene expression. The Janus kinase (JAK)-signal transducer and activator of (STAT) transcription factors receptors [199], and the p38 mitogen-activated protein kinases (MAK) play a central role in coordinating the immune system. Through phosphorylation, these pathways respond to cytokines and other external stimuli and subsequently control cytokine gene expression.

\section{p38 MAP Kinase (p38 MAPK) Regulation of Proinflammatory Cytokines}

The p38 mitogen-activated protein kinases serve as an intracellular signaling pathway, essential for immune function and inflammation. P38 responds to external stresses such as infection, thermal shock, osmotic shock, and ultraviolet radiation, activating downstream targets, including several kinases, transcription factors, and cytosolic proteins. The activated transcription factor NF-kB upregulates cytokine genes, producing an inflammatory response [193] In a positive feedback loop, cytokines then activate the same p38 MAPK protein. The p38 
MAPK pathway is a key regulator of pro-inflammatory cytokine production at the transcriptional and translational levels [8,44] [Figure 4].

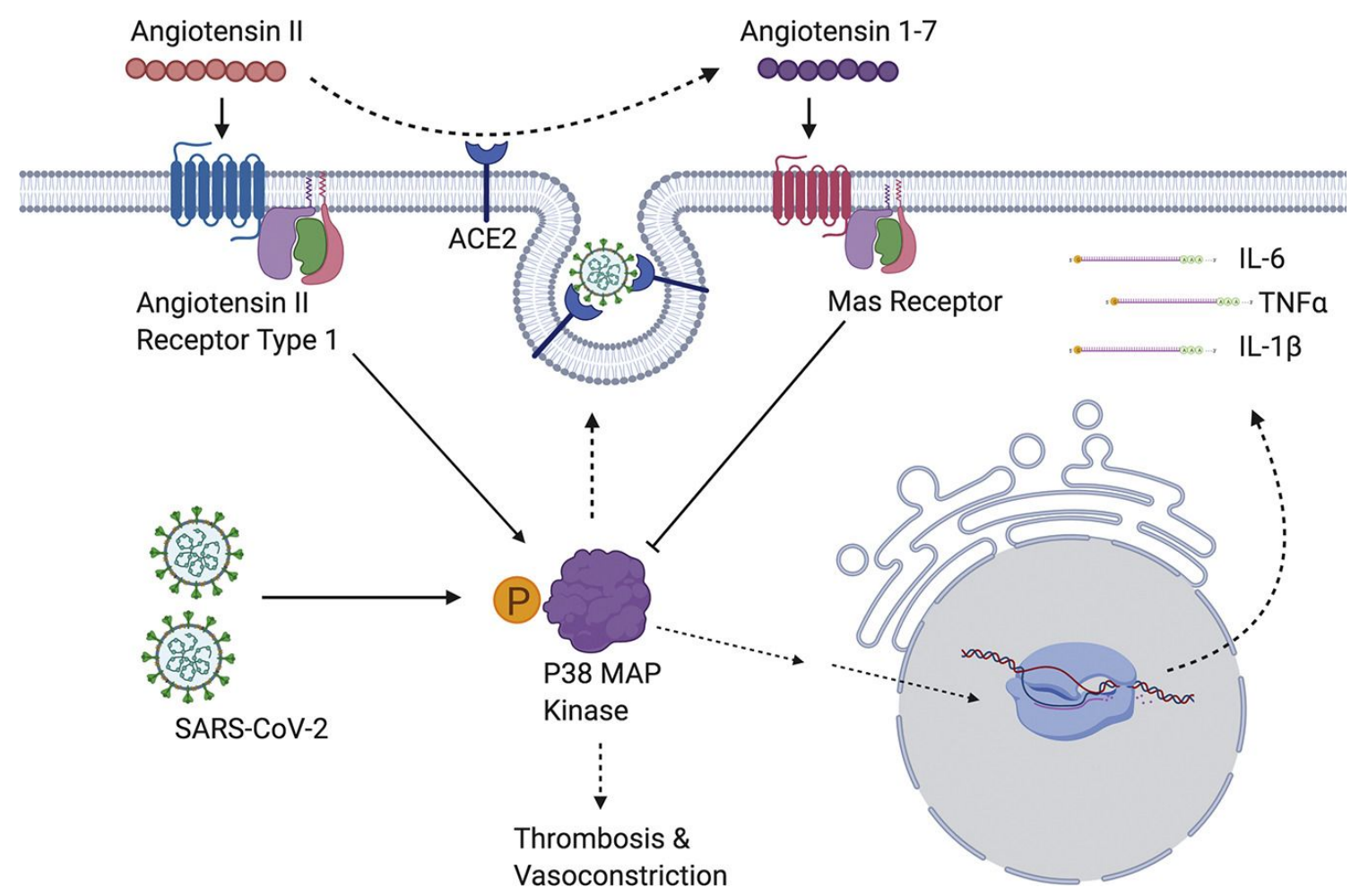

Figure 4. SARS-CoV-2 induces overwhelming inflammation by directly activating p38 and downregulating the Ang1-7 inhibitory pathway [92]. (http://creativecommons.org/licenses/by/4.0/)

Macrophages are the first line of innate immunity, producing various cytokines and chemokines [3]. Inflammasomes are intracellular protein complexes that respond to external infection or stress to activate the pro-inflammatory cytokines IL-1b and IL-18 as part of the innate immune response [198]. P38 plays a vital role in macrophage-mediated inflammation through phosphorylation and activation of inflammatory genes, downstream mediators, and inflammasomes [44,72].

Regulating the p38 MAPK pathway prevents runaway inflammation. Downregulation of p38 can occur through direct dephosphorylation [106]. MK2 and MK3 are downstream mitogen-activated kinases that are exclusively activated by p38 MAPK. MK2 and MK3 play essential roles in regulating p38 MAPK [206]. Genetically modified mice with "knockouts" of p38 MAPK or its downstream substrates MK2 and MK3 provide insights into these protein kinases' role in disease models. In a mouse model with pemphigus vulgaris, inhibitors of p38 
MAPK turned off cytokine release and prevented the blistering characteristic of the skin disease [15].

In an autoimmune encephalomyelitis model, MK2 exerts marked anti-inflammatory effects on p38 MAPK signaling. In MK2 knockout mice, in which the normal inhibitory function of the MK2 on p38 MAPK is blocked, there was a severe worsening of the clinical course [210].

The SAR-CoV virus utilizes p38 MAPK phosphorylation in infected cells to activate physiological intracellular signaling [157]. SARS-CoV-2 directly upregulates p38 MAPK genes, rewiring host cell phosphorylations in 97 of 518 human kinases. This results in p38 MAPK activation, production of various cytokines, the shutdown of mitotic kinases, and cell cycle arrest [23]. By potentiating the p38 pathway with gene upregulation and blocking p38 MAPK inhibitors, SARS-Cov- 2 increases cytokine production, resulting in worsening inflammation and disease progression $[92,157]$.

\section{Modification of Gene Expression Through Transcription Factors and Epigenetics}

Cytokine gene expression is controlled by a network of transcription factors, including Nuclear Factor-kB (NF- $\kappa \mathrm{B}$ ), which is upregulated by SARS-COV-2 $[99,135]$. NF- $\kappa$ B induces the expression of hundreds of proinflammatory and immune genes encoding for cytokines and chemokines and is a central controlling pathway for inflammation [135]. The p38 MAPK pathway regulates the transcriptional activity of NF- $\kappa$ B through phosphorylation [193].

Epigenetics describes the genetic and non-genetic factors that control or modify gene expression without altering the underlying DNA code. These external or environmental factors interact with the host DNA, leading to phenotypic variation. Epigenetics mechanisms include DNA methylation, histone modifications, and chromatin remodeling [244][Figure 5].

Epigenetics and transcriptional factors shape the adaptive immune response and provide a model to understand the genetic basis for the broad clinical spectrum encountered with SARS-CoV-2 infections [66,227]. 


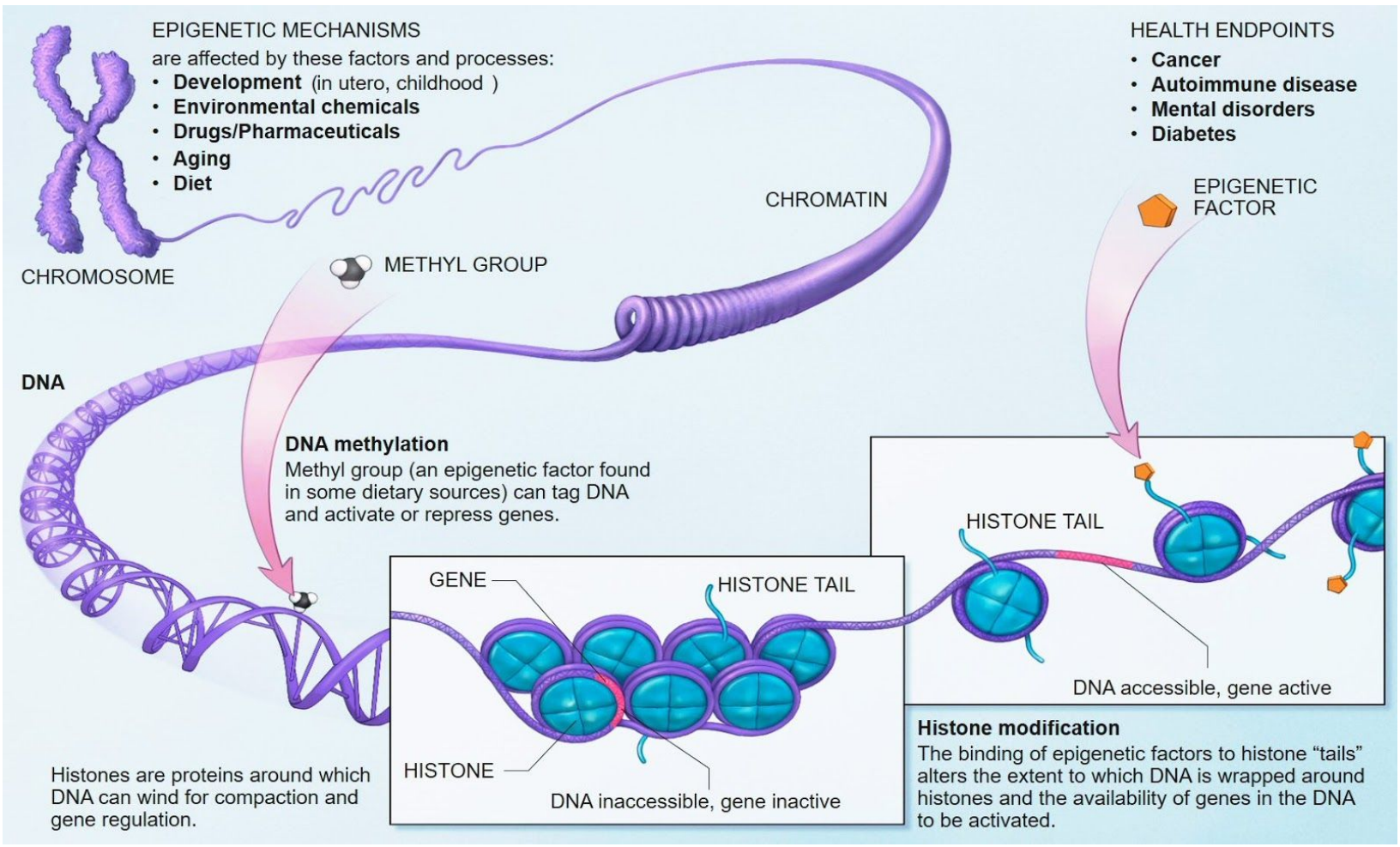

Figure 5. Epigenetic mechanisms altering gene expression. Scientific Illustration of How Epigenetic Mechanisms Can Affect Health National Institutes of Health (http://creativecommons.org/licenses/by/4.0/)

In systemic lupus erythematosus, epigenetic modifications of cytokine genes and p38 MAPK disrupt immune homeostasis, producing elevated proinflammatory cytokines [97]. In oncology patients, aberrant epigenetic modification of cytokine genes is involved in tumor initiation, invasion, and progression [244].

Coronavirus pathophysiology and disease severity are closely linked to epigenetic mechanisms, promoting viral entry, replication, evasion of host defenses, and immune hyperactivation $[66,182]$. There are remarkably 464 upregulated and 222 downregulated genes for the SARS-CoV-2 infection in the complex interaction between host and virus [117].

Transcriptional factors and viral epigenetic modification of host DNA expression result in loss of normal cytokine release regulation [121,244]. SARS-CoV-2 upregulates the p38 MAPK gene through phosphorylation, resulting in the production of a diverse spectrum of cytokines [23]. These modifications can lead to increased inflammatory gene expression or loss of inhibition of the p38 MAPK signaling pathway. 


\section{Genetic Polymorphisms Determine Differences in Symptoms and Clinical Severity}

Genetic polymorphism in the cytokine genes' regulatory regions can explain interindividual differences in the severity and symptoms of COVID-19. Different alleles of the cytokine genes affect the level and ratio of cytokines produced, altering the autoimmune and inflammatory response [100].

Long COVID post-viral syndrome may be related to genetic predisposition. Single nucleotide polymorphisms of cytokine genes IL-6, TNF- $\alpha$, IFN- $\gamma$, and IL-10 correlate with post-viral fatigue, pain, neurocognitive difficulties, and mood disturbances, respectively. Increased fatigue post-infection is associated with the T allele of IFN- $\gamma+874$ T/A SNP [180]. Overall severity and duration of post-viral symptoms are associated with polymorphisms in the IFN- $\gamma$ and IL-10 genes [230].

Ethnic differences in clinical severity are based upon polymorphisms. Blacks with a worse COVID-19 clinical course demonstrate increased expression of cytokine polymorphic alleles for IL-6, IL-10, and IL-2, resulting in higher expression than Whites $[43,100,247]$ and higher plasma levels of IL-6 [176].

For COVID-19, polymorphisms of other genes encoding for ACE1/ACE II, immunity, inflammation, and coagulation may also play roles in determining susceptibility and clinical course $[57,89]$.

\section{Other factors contributing to the Cytokine Release Syndrome (CRS)}

Oxidative stress (OS). An imbalance between production and accumulation of reactive oxygen species (ROS) causes oxidative stress. When oxygen-free radicals exceed antioxidant capacity, OS can trigger inflammation or result from cytokine release and inflammation [26]. OS and CRS are closely related and interdependent processes. Positive feedback loops between OS and CRS result in amplifying the clinical effect and a potentially vicious cycle of OS and inflammation $[19,67]$. For chronic diseases, low-grade inflammation and OS are tightly linked and interdependent processes [19]. The signaling link between OS and cytokines involves the p38 MAPK $[168,207]$. Combined antioxidant and anti-inflammatory therapy provides an intriguing two-pronged approach to treating the chronic inflammation of the Long COVID patients $[190,224]$.

Bradykinin. Bradykinin, a nine-amino acid peptide, promotes inflammation, vasodilatation, and increased vascular permeability, causing edema and pain [146]. In acute, severe COVID-19, there is increased bradykinin expression and reduced bradykinin breakdown by ACE [87]. Bradykinin, the Renin-Angiotensin System (RAS), and cytokines are closely and synergistically 
linked. Bradykinin stimulates the release of cytokines and chemokines, including TNF alpha, IL-1, IL-6, and IL-8 [74] via p38 MAPK pathways [96]. Conversely, cytokines induce the bradykinin $\mathrm{B} 1$ and $\mathrm{B} 2$ receptors [93].

\section{Defining the Long COVID Patient Group}

The Long COVID group is heterogeneous, representing different disease processes and patient subgroups, only unified by their persistent and relapsing symptoms. These groups include those with mild to moderate COVID-19 and post-viral syndrome, patients with end-organ pulmonary or cardiac dysfunction, post ICU syndrome, and those with ongoing active infection [136].

The cytokine syndrome release model for the pathophysiology of Long COVID symptoms assumes no underlying end-organ damage. This may not be true for all patients, especially those who were previously hospitalized. Hospitalized patients with moderate-to-severe COVID-19 can have residual pulmonary and cardiac dysfunction due to end-organ damage [60]. A 15 -year follow-up of SARS patients showed $4.6 \%$ with CT findings of lung scarring and corresponding PFT changes, indicating decreased lung function [248]. In the immediate convalescent-phase, over half of the patients with severe COVID-19 showed impaired lung function with decreased diffusing capacity (DLCO) on PFTs [104,166]. COVID-19 cardiac dysfunction is well recognized. In one study, $55 \%$ of patients showed an abnormal echocardiogram, $46 \%$ without previous cardiac history [64]. These patients with organic disease will also experience fatigue and dyspnea with exertion. However, their symptoms should be immediate in contrast to the Long COVID patients, whose symptoms are delayed by 1-2 days following exertion. In Long COVID patients with exertional dyspnea and fatigue, pulmonary and cardiac evaluation should be considered to exclude unsuspected end-organ injury. To our knowledge, this is not currently being performed routinely.

\section{The Site of Initial Infection May Determine the Pathway to Two Distinct COVID-19 Diseases}

The site and dosage of the initial viral infection and the host immune response are important in determining the clinical course. Lower respiratory tract localization of the viral infection leads to a more severe clinical course with COVID-19 pneumonia, a peripheral cytokine response, multiorgan involvement, seroconversion, and a more rapid course leading to recovery for those who do not succumb to the disease [242].

Nasopharyngeal localization of the virus in the upper respiratory tract impacts olfactory function and leads to a milder clinical course. In one study, patients with anosmia, indicating upper respiratory tract infection, were ten times less likely to undergo hospital admission for COVID-19 [242] 
Some upper respiratory tract patients will undergo olfactory to CNS spread, leading to microglial activation and neuroinflammation. Covert viral infections affecting the olfactory bulb can induce neuroinflammation by activating microglia, leading to neurodegenerative disease [140].

Direct invasion of the olfactory epithelium by SARS-CoV-2 can occur [132]. ACE-2 receptors are present in the olfactory epithelium, support cells, pericytes, and olfactory bulb but not olfactory neurons [24]. Other pathways for olfactory-to-CNS spread could involve perivascular spaces or lymphatics and CSF [132]. Alternatively, indirect CNS effects are possible. A local nasal viral infection can activate inflammatory $T$ cells that ascend into the brain along olfactory sensory nerves, producing autoimmune neuroinflammation [181].

This presentation is consistent with many Long COVID patients, manifesting symptoms of SARS-CoV-2 neurovirulence with CNS cytokine cascades $[55,126]$. A persistent CNS infection occurs since the blood-brain barrier establishes the brain's protected immune status [226].

There are intriguing differences between the hospitalized acutely ill patients and the non-hospitalized Long COVID patients. In one study of 153 PRC positive COVID patients, non-hospitalized patients were more likely to have neurological symptoms, were less likely to develop pneumonia, showed slower recovery (>8 weeks, $30 \%$ vs. $0 \%$ ), and impaired IgG seroconversion [62] suggesting insufficient virus-specific antibody response and potential latent infection. SARS-CoV-2 might function as a neurotropic virus and establish prolonged infections in neurons, similar to herpes zoster [62]. Anterograde dissemination of the virus along cranial and peripheral nerves has been hypothesized with multiorgan involvement [73].

Other studies confirm the increased frequency of CNS symptoms amongst the Long COVID patients. A meta-analysis of 92 COVID-19 studies reported headaches in $20 \%$, dizziness in $6.8 \%$, and impaired consciousness in $5 \%$ of patients [32]. In comparison, the Long COVID survey reported $>60 \%$ of Long COVID patients report headache, dizziness, and impaired consciousness (brain fog) [5].

Some of the less typical Long COVID symptoms could be due to brainstem involvement with retrograde neuroinvasion along other cranial nerves [61,63]. Brainstem neuroinflammation observed at autopsy with COVID-19 [145] results in symptoms from cranial nerve and brainstem nuclei involvement $[14,110]$. Brainstem dysfunction symptoms include many reported by Long COVID patients with dizziness, blurred vision, visual and auditory disturbances, flushing, vertigo, numbness, tinnitus, dysphagia, irregular heartbeat, diarrhea, loss of thermoregulation, altered sleep, and ANS dysfunction, including POTS [33,221]. 


\section{Gender Differences in Long COVID Group}

The prevalence of women in the Long COVID cohort is intriguing, with a 4:1 female: male ratio in one study [56]. The hyperimmune effects of estrogen leading to increased cytokine response and predisposition of autoimmunity is well described [220]. In addition, a meta-analysis indicated that women have superior olfactory abilities [208]. An anatomical basis was confirmed in an autopsy study, showing women have $43 \%$ more olfactory bulb cells than men and $50 \%$ more olfactory neurons [175]. It seems reasonable that the increased number of olfactory cells in women would increase the risk for viral spread via the olfactory-to-CNS route [91].

In a study of olfactory and gustatory dysfunction in patients with mild to moderate COVID-19, females were significantly more affected than males $(p<.001)$ [127]. A study of Long vs. Short COVID, found that the development of Long COVID was predicted by fatigue, headache, dyspnea, and anosmia at seven days [216]. Notably, all of these symptoms are CNS mediated and reflect upper respiratory tract infection.

\section{Myalgic Encephalomyelitis/Chronic Fatigue Syndrome (ME/CFS)}

The chronic and relapsing symptoms of the Long COVID patients have been compared to those of ME/CFS. The complex underlying biology and pathophysiology of ME/CFS have been debated. It involves peripheral immune activation, altered energy metabolism, epigenetic DNA modifications, and for most, an infectious trigger with autoimmunity [18].

Peripheral Immune Activation and Inflammation in ME/CFS. Lines of evidence indicate that ME/CFS and other neurodegenerative and neuroinflammatory diseases involve peripheral immune activation, inflammation and oxidative stress, gray matter atrophy, glucose hypometabolism and cerebral hypoperfusion [162]. This immune-inflammatory model in the pathogenesis ME/CFS involves elevated proinflammatory cytokines $[107,160,165]$. Alterations in Blood and CSF cytokine levels have been described with 17 cytokines correlating with disease severity $[21,65,160,191]$.

Plasma cytokine levels measured twice daily over 25 days correlated with fatigue levels in ME/CFS volunteers. Twelve cytokines were consistently elevated on high-fatigue days. Evaluating cytokine patterns yielded a $78 \%$ accuracy in predicting low vs. high-fatigue days [214].

Bioenergetic Abnormalities in ME/CFS. Proinflammatory cytokines and OS potentiate the mitochondrial dysfunction in ME/CFS, resulting in glucose hypometabolism and decreased ATP [164]. Blockage of the TCA cycle, leading to less efficient metabolism, has been proposed [79]. Mitochondria provide the metabolites essential for chromatin remodeling and DNA 
methylation in epigenetic DNA modifications [144]. Dysfunctional mitochondria also contribute to microglial activation and neuroinflammation [34]

Epigenetics in ME/CFS. Epigenetics has been explored in patients with ME/CFS [229]. The authors noted 12,608 differentially methylated sites when comparing ME/CFS patients and healthy controls. Glucocorticoid sensitivity in ME/CFS patients was associated with specific epigenetic markers. Another study [228] showed 307 differentially methylated DNA promoters participating in 15 cell signaling pathways with a predominant immune component. $98 \%$ of epigenetic changes involved hypomethylation leading to increased gene expression [228]. In $\mathrm{ME} / \mathrm{CFS}$, deregulated and elevated NF-kB transcription factors and decreased p53 also increase inflammatory gene expression [163].

Infections and Autoimmunity in ME/CFS. Two-thirds of cases have an infectious onset with numerous viruses implicated in ME/CFS [188]. The role of viral infections in ME/CFS pathogenesis may be related to immune system dysfunction, mitochondrial modulations, and or autoimmunity [188]. A recent study of ME/CFS patients showed two single nucleotide polymorphisms associated with autoimmune disease [212], present in infectious ME/CFS patients but absent in noninfectious ME/CFS patients and controls. Notably, the affected genes involved $B$ and $T$ cell activation, cytokine production, and cytokine signaling.

A model of ME/CFS pathogenesis involving an infectious trigger, autoimmunity, and elevated pro-inflammatory cytokines has been proposed [21]. In genetically predisposed individuals, chronic inflammation, and epigenetic changes in gene expression, result in autoimmunity [147] [Figure 6].

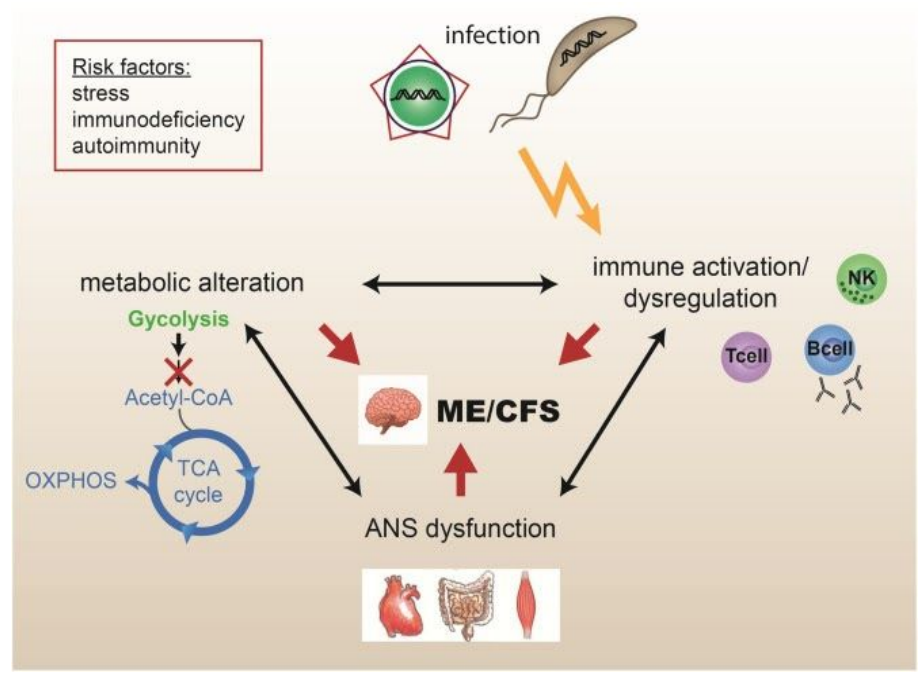

Figure 6. Potential pathomechanism of ME/CFS. Dysregulation of the immune system, autonomic nervous system (ANS) and metabolic disturbances contribute to this complex 
syndrome. In most patients, disease onset is triggered by infection with stress, immunodeficiency and autoimmunity as known risk factors [209] (http://creativecommons.org/licenses/by/4.0/)

\section{Experience from Post SARS Patients who Experience Chronic Fatigue Syndrome}

Following other epidemics, including the 2003 SARS epidemic, a group of patients showed symptoms of chronic fatigue and sleep disturbances, very similar to those of the Long COVID patients [108,123]. Follow up of 233 survivors at four years showed $40.3 \%$ with ongoing chronic fatigue, with $27.1 \%$ meeting the modified 1994 CDC criteria for CFS. In personal communication with the author regarding ongoing follow up of these patients, Dr. Lam indicated that 100 patients were being followed for chronic fatigue at four years. Now, 17 years after the SARS outbreak, 70 patients showed interval resolution of symptoms, while $30(13 \%)$ progressed to chronic illness with ongoing fatigue and sleep disturbance. A few patients with hypocortisolism responded to steroid replacement therapy. In the majority, there was no correlation between fatigue severity and salivary cortisol levels. Management of mood symptoms, insomnia, and regulation of circadian rhythm has provided the most promising results.

\section{Progression to ME/CFS and the Role of Autoimmunity}

Why some patients with post-viral syndrome progress to ME/CFS is a critical issue that can involve polymorphic genetic predisposition, an environmental or infectious trigger, and immune system dysregulation [65].

Chronic systemic inflammation leads to a host of illnesses, including autoimmune diseases [82]. Since the autoimmune model for post-infectious ME/CFS is increasingly recognized $[82,212]$ [209], this could be a determining factor in the progression from post-viral syndrome to ME/CFS.

The viral triggering of autoimmunity is intimately associated with cytokines [111] and epigenetic alterations of gene expression [2]. It is known that coronaviruses trigger autoimmunity. The SARS-CoV virus-induced autoantibodies against lung epithelial cells [133]. SARS-CoV-2 infection has precipitated a host of autoimmune diseases, including multisystem inflammatory syndrome in children (MIS-C) [65,84].

In a sense, the story ends where it began, in that cytokines are central to the pathogenesis of many autoimmune diseases [111]. Autoimmunity involves the balance of cytokines produced by Th1 and Th2 cells and other cytokines, including IL-17/LK-23 [111]. An intriguing possible target for autoimmunity is the neuroprotective cytokine, IL1-ra, whose role may prevent the shift from acute inflammation to the chronic state following infection. IL1-ra normally balances the inflammatory effects of cytokine IL-1 $\beta$. In an experimental model of fatigue from 
neuroinflammation, neutralizing antibodies against IL1-ra significantly delayed recovery, which could induce chronic neuroinflammation [240,241][Figure 7].

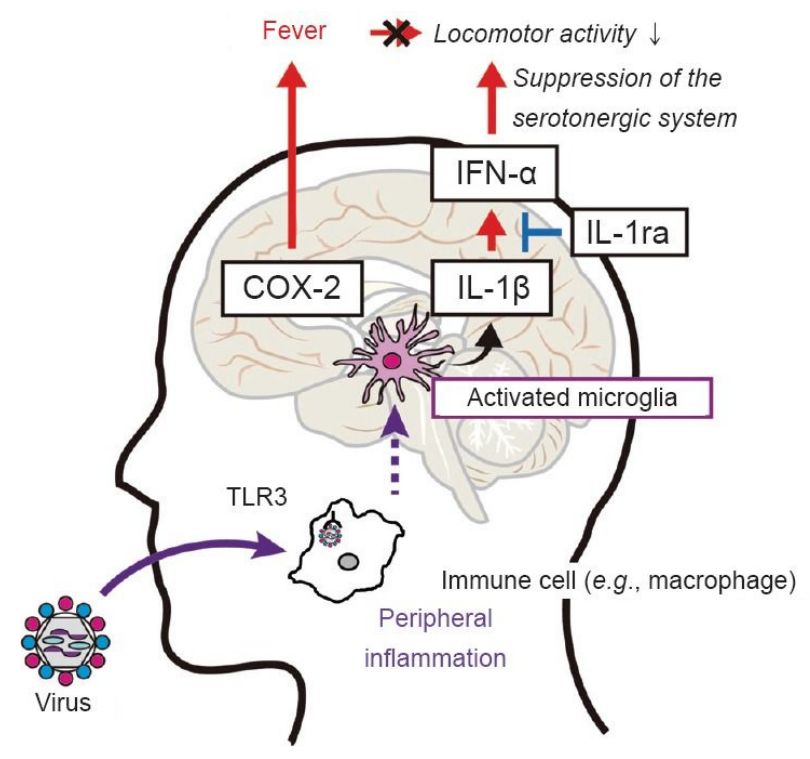

Figure 7. Molecular mechanism of transient fever and suppression of locomotor activity (fatigue) following viral infection [240]. IL-1ra prevents shift from acute to chronic inflammatory state.

For the Long COVID patients, continuing cytokine expression can produce a low-grade chronic inflammatory state, which can further lead to activated, dysregulated microglia and neuroinflammation. A working hypothesis is that some patients will have a genetic polymorphism predisposing them to autoimmunity. Epigenetic changes in gene expression induced by the virus or other external factors may provide the trigger that initiates the progression to autoimmunity and ME/CFS.

\section{Final Thoughts}

The proposed explanation of the pathophysiology of the persistent symptoms of the Long COVID patients is likely incomplete. However, it provides a reasonable model to consider the pathophysiology of the plight of the millions of persons who are stuck in a seemingly never-ending recovery from COVID-19. There is some common underlying pathophysiology between the Long COVID patients and other chronic diseases, but we suspect this is a unique group. At least, only a subset of the Long COVID cohort will progress to CFS. Understanding what makes them unique and how to find the pathway to full recovery is the next part of their journey. We hope this essay sheds light on how their current clinical problems are based on the science of cytokines and their controlling signaling pathways. 


\section{Acknowledgments}

We thank M. Horan, Y. Re'em, and M.B. Barnkob for their valuable inputs on the manuscript. We thank members of the Patient-Led Research For COVID19 for their support and inspirations. We thank members of the Body Politic Online COVID19 Support Group for sharing their experiences.

\section{References}

[1] Aid M, Busman-Sahay K, Vidal SJ, Maliga Z, Bondoc S, Starke C, Terry M, Jacobson CA, Wrijil L, Ducat S, Brook OR, Miller AD, Porto M, Pellegrini KL, Pino M, Hoang TN, Chandrashekar A, Patel S, Stephenson K, Bosinger SE, Andersen H, Lewis MG, Hecht JL, Sorger PK, Martinot AJ, Estes JD, Barouch DH. Vascular Disease and Thrombosis in SARS-CoV-2-Infected Rhesus Macaques. Cell 2020. doi:10.1016/j.cell.2020.10.005.

[2] Anna Elisa Andrea Surace $\mathrm{CMH}$. The Role of Epigenetics in Autoimmune/Inflammatory Disease. Front Immunol 2019;10. doi:10.3389/fimmu.2019.01525.

[3] Arango Duque G, Descoteaux A. Macrophage cytokines: involvement in immunity and infectious diseases. Front Immunol 2014;5:491. doi:10.3389/fimmu.2014.00491.

[4] Arnold DT, Hamilton FW, Milne A, Morley A, Viner J, Attwood M, Noel A, Gunning S, Hatrick J, Hamilton S, Elvers KT, Hyams C, Bibby A, Moran E, Adamali H, Dodd J, Maskell NA, Barratt S. Patient outcomes after hospitalisation with COVID-19 and implications for follow-up; results from a prospective UK cohort. n.d. doi:10.1101/2020.08.12.20173526.

[5] Assaf, G., Davis, H., McCorkell, L., Wei, H., O’Neill, B., \& Akrami, A., Low, R., Mercier, J., Adetutu A. What Does COVID-19 Recovery Actually Look Like? An Analysis of the Prolonged COVID-19 Symptoms Survey by Patient-Led Research Team. Patient-Led Research Team London, UK: The COVID-19 Body Politic Slack Group; 2020. Available: patientresearchcovid19.com. Accessed May 2020.

[6] Astudillo L, Laure A, Fabry V, Pugnet G, Maury P, Labrunée M, Sailler L, Pavy-Le Traon A. Le syndrome de tachycardie posturale (PoTS) : une maladie pour l'interniste. La Revue de Médecine Interne 2018;39:627-634. doi:10.1016/j.revmed.2018.04.017.

[7] Avanzato VA, Jeremiah Matson M, Seifert SN, Pryce R, Williamson BN, Anzick SL, Barbian K, Judson SD, Fischer ER, Martens C, Bowden TA, de Wit E, Riedo FX, Munster VJ. Case Study: Prolonged infectious SARS-CoV-2 shedding from an asymptomatic immunocompromised cancer patient. Cell 2020. doi:10.1016/j.cell.2020.10.049.

[8] Bachstetter AD, Van Eldik LJ. The p38 MAP Kinase Family as Regulators of Proinflammatory Cytokine Production in Degenerative Diseases of the CNS. Aging Dis 2010;1:199-211. Available: https://www.ncbi.nlm.nih.gov/pubmed/22720195.

[9] Badham SP, Hutchinson CV. Characterising eye movement dysfunction in myalgic 
encephalomyelitis/chronic fatigue syndrome. Graefes Arch Clin Exp Ophthalmol 2013;251. doi:10.1007/s00417-013-2431-3.

[10] Bakhoum MF, Ritter M, Garg A, Chan AX, Bakhoum CY, Smith D. Subclinical ocular inflammation in persons recovered from ambulatory COVID-19. n.d. doi:10.1101/2020.09.22.20128140.

[11] Balter LJ, Bosch JA, Aldred S, Drayson MT, van Zanten JJ V, Higgs S, Raymond JE, Mazaheri A. Selective effects of acute low-grade inflammation on human visual attention. Neuroimage 2019;202. doi:10.1016/j.neuroimage.2019.116098.

[12] Barbosa-Silva MC, Santos LE, Rangel B. The Impact of Non-Neurotropic Influenza Strains on the Brain: A Role for Microglial Priming? J Neurosci 2018;38:7758-7760. doi:10.1523/JNEUROSCI.1368-18.2018.

[13] Behrens K, Alexander WS. Cytokine control of megakaryopoiesis. Growth Factors 2018;36. doi:10.1080/08977194.2018.1498487.

[14] Benghanem S, Mazeraud A, Azabou E, Chhor V, Shinotsuka CR, Claassen J, Rohaut B, Sharshar T. Brainstem dysfunction in critically ill patients. Crit Care 2020;24. doi:10.1186/s13054-019-2718-9.

[15] Berkowitz P, Hu P, Warren S, Liu Z, Diaz LA, Rubenstein DS. p38MAPK inhibition prevents disease in pemphigus vulgaris mice. Proc Natl Acad Sci U S A 2006;103:12855-12860. doi:10.1073/pnas.0602973103.

[16] von Bernhardi R, Bernhardi LE, Eugenín J. Microglial cell dysregulation in brain aging and neurodegeneration. Front Aging Neurosci 2015;7. doi:10.3389/fnagi.2015.00124.

[17] Besedovsky HO, del Rey A. The cytokine-HPA axis feed-back circuit. Z Rheumatol 2000;59 Suppl 2. doi:10.1007/s003930070014.

[18] Biomedical Insights that Inform the Diagnosis of ME/CFS. n.d. Available: https://books.google.com/books/about/Biomedical_Insights_that_Inform_the_Diag.html?id=ttzW DwAAQBAJ. Accessed 23 Aug 2020.

[19] Biswas SK. Does the Interdependence between Oxidative Stress and Inflammation Explain the Antioxidant Paradox? Oxid Med Cell Longev 2016;2016. doi:10.1155/2016/5698931.

[20] Blair PW, Brown DM, Jang M, Antar AAR, Keruly JC, Bachu V, Townsend JL, Tornheim JA, Keller SC, Sauer L, Thomas DL, Manabe YC, Ambulatory COVID Study Team. The clinical course of COVID-19 in the outpatient setting: a prospective cohort study. n.d. doi:10.1101/2020.09.01.20184937.

[21] Blomberg J, Gottfries C-G, Elfaitouri A, Rizwan M, Rosén A. Infection Elicited Autoimmunity and Myalgic Encephalomyelitis/Chronic Fatigue Syndrome: An Explanatory Model. Front Immunol 2018;9. doi:10.3389/fimmu.2018.00229.

[22] Bohmwald K, Gálvez NMS, Ríos M, Kalergis AM. Neurologic Alterations Due to Respiratory Virus Infections. Front Cell Neurosci 2018;12:386. doi:10.3389/fncel.2018.00386.

[23] Bouhaddou M, Memon D, Meyer B, White KM, Rezelj VV, Correa Marrero M, Polacco BJ, Melnyk JE, Ulferts S, Kaake RM, Batra J, Richards AL, Stevenson E, Gordon DE, Rojc A, Obernier K, Fabius JM, Soucheray M, Miorin L, Moreno E, Koh C, Tran QD, Hardy A, Robinot R, Vallet T, Nilsson-Payant BE, 
Hernandez-Armenta C, Dunham A, Weigang S, Knerr J, Modak M, Quintero D, Zhou Y, Dugourd A, Valdeolivas A, Patil T, Li Q, Hüttenhain R, Cakir M, Muralidharan M, Kim M, Jang G, Tutuncuoglu B, Hiatt J, Guo JZ, Xu J, Bouhaddou S, Mathy CJP, Gaulton A, Manners EJ, Félix E, Shi Y, Goff M, Lim JK, McBride T, O'Neal MC, Cai Y, Chang JCJ, Broadhurst DJ, Klippsten S, De Wit E, Leach AR, Kortemme T, Shoichet B, Ott M, Saez-Rodriguez J, tenOever BR, Mullins RD, Fischer ER, Kochs G, Grosse R, García-Sastre A, Vignuzzi M, Johnson JR, Shokat KM, Swaney DL, Beltrao P, Krogan NJ. The Global Phosphorylation Landscape of SARS-CoV-2 Infection. Cell 2020;182:685-712.e19. doi:10.1016/j.cell.2020.06.034.

[24] Brann DH, Tsukahara T, Weinreb C, Lipovsek M, den Berge K V, Gong B, Chance R, Macaulay IC, Chou HJ, Fletcher RB, Das D, Street K, de Bezieux HR, Choi YG, Risso D, Dudoit S, Purdom E, Mill J, Hachem RA, Matsunami H, Logan DW, Goldstein BJ, Grubb MS, Ngai J, Datta SR. Non-neuronal expression of SARS-CoV-2 entry genes in the olfactory system suggests mechanisms underlying COVID-19-associated anosmia. Science advances 2020;6. doi:10.1126/sciadv.abc5801.

[25] Butler M, Pollak TA, Rooney AG, Michael BD, Nicholson TR. Neuropsychiatric complications of covid-19. BMJ 2020:m3871. doi:10.1136/bmj.m3871.

[26] Camhi SL, Lee P, Choi AM. The oxidative stress response. New Horiz 1995;3:170-182. Available: https://europepmc.org/article/med/7583159?client=bot. Accessed 5 Oct 2020.

[27] Capuron L, Dantzer R. Cytokines and depression: the need for a new paradigm. Brain Behav Immun 2003;17 Suppl 1:S119-24. doi:10.1016/s0889-1591(02)00078-8.

[28] Carfi A, Bernabei R, Landi F. Persistent Symptoms in Patients After Acute COVID-19. JAMA 2020;324:603-605. doi:10.1001/jama.2020.12603.

[29] Carson MJ, Thrash JC, Walter B. The cellular response in neuroinflammation: The role of leukocytes, microglia and astrocytes in neuronal death and survival. Clin Neurosci Res 2006;6:237-245. doi:10.1016/j.cnr.2006.09.004.

[30] Cevik M, Bamford CGG, Ho A. COVID-19 pandemic-a focused review for clinicians. Clin Microbiol Infect 2020;26:842. doi:10.1016/j.cmi.2020.04.023.

[31] Chaudhuri A, Behan PO. Fatigue and basal ganglia. J Neurol Sci 2000;179. doi:10.1016/s0022-510x(00)00411-1.

[32] Chen X, Laurent S, Onur OA, Kleineberg NN, Fink GR, Schweitzer F, Warnke C. A systematic review of neurological symptoms and complications of COVID-19. J Neurol 2020. doi:10.1007/s00415-020-10067-3.

[33] Chigr F, Merzouki M, Najimi M. Autonomic Brain Centers and Pathophysiology of COVID-19. ACS Chem Neurosci n.d. doi:10.1021/acschemneuro.0c00265.

[34] Chiurazzi M, Di Maro M, Cozzolino M, Colantuoni A. Mitochondrial Dynamics and Microglia as New Targets in Metabolism Regulation. Int J Mol Sci 2020;21. doi:10.3390/ijms21103450.

[35] Church MK, McGill JI. Human ocular mast cells. Curr Opin Allergy Clin Immunol 2002;2. doi:10.1097/00130832-200210000-00009. 
[36] Cirulli E, Schiabor Barrett KM, Riffle S, Bolze A, Neveux I, Dabe S, Grzymski JJ, Lu JT, Washington NL. Long-term COVID-19 symptoms in a large unselected population. n.d.

doi:10.1101/2020.10.07.20208702.

[37] Clark AK, Old EA, Malcangio M. Neuropathic pain and cytokines: current perspectives. J Pain Res 2013;6. doi:10.2147/JPR.S53660.

[38] Connors JM, Levy JH. COVID-19 and its implications for thrombosis and anticoagulation. Blood 2020;135. doi:10.1182/blood.2020006000.

[39] Conti B, Tabarean I, Andrei C, Bartfai T. Cytokines and fever. Front Biosci 2004;9. doi:10.2741/1341.

[40] Coperchini F, Chiovato L, Croce L, Magri F, Rotondi M. The cytokine storm in COVID-19: An overview of the involvement of the chemokine/chemokine-receptor system. Cytokine Growth Factor Rev 2020;53:25-32. doi:10.1016/j.cytogfr.2020.05.003.

[41] Cordeiro LMS, Rabelo PCR, Moraes MM, Teixeira-Coelho F, Coimbra CC, Wanner SP, Soares DD. Physical exercise-induced fatigue: the role of serotonergic and dopaminergic systems. Braz J Med Biol Res 2017;50. doi:10.1590/1414-431X20176432.

[42] Corominas H, Alegre C, Narváez J, Fernández-Cid CM, Torrente-Segarra V, Gómez MR, Pan FM, Morlà RM, Martínez FJR, Gómez-Centeno A, Ares LL, Molina RG, González-Albo SP, Dalmau-Carolà J, Pérez-García C, Álvarez CB, Ercole L, Terrancle MÁ. Correlation of fatigue with other disease related and psychosocial factors in patients with rheumatoid arthritis treated with tocilizumab: ACT-AXIS study. Medicine 2019;98. doi:10.1097/MD.0000000000015947.

[43] Cox ED, Hoffmann SC, DiMercurio BS, Wesley RA, Harlan DM, Kirk AD, Blair PJ. Cytokine polymorphic analyses indicate ethnic differences in the allelic distribution of interleukin-2 and interleukin-6. Transplantation 2001;72. doi:10.1097/00007890-200108270-00027.

[44] Cuenda A, Rousseau S. p38 MAP-Kinases pathway regulation, function and role in human diseases. Biochimica et Biophysica Acta (BBA) - Molecular Cell Research 2007;1773:1358-1375. doi:10.1016/j.bbamcr.2007.03.010.

[45] Cytokines and chemokines: At the crossroads of cell signalling and inflammatory disease. Biochimica et Biophysica Acta (BBA) - Molecular Cell Research 2014;1843:2563-2582. doi:10.1016/j.bbamcr.2014.05.014.

[46] Cytokines and their receptors in the central nervous system: Physiology, pharmacology, and pathology. Pharmacol Ther 1996;69:85-95. doi:10.1016/0163-7258(95)02033-0.

[47] Cytokines and the nervous system II: actions and mechanisms of action. Trends Neurosci 1995;18:130-136. doi:10.1016/0166-2236(95)93890-A.

[48] Cytokines in the balance. Nature Immunology 2019;20:1557-1557. doi:10.1038/s41590-019-0557-0.

[49] D'Amico F, Baumgart DC, Danese S, Peyrin-Biroulet L. Diarrhea During COVID-19 Infection: Pathogenesis, Epidemiology, Prevention, and Management. Clinical Gastroenterology and Hepatology 2020;18:1663-1672. doi:10.1016/j.cgh.2020.04.001. 
[50] Dantzer R. Cytokine-induced sickness behavior: where do we stand? Brain Behav Immun 2001;15:7-24. doi:10.1006/brbi.2000.0613.

[51] Dantzer R. Cytokine, sickness behavior, and depression. Immunol Allergy Clin North Am 2009;29:247-264. doi:10.1016/j.iac.2009.02.002.

[52] Dantzer R. Neuroimmune Interactions: From the Brain to the Immune System and Vice Versa. Physiol Rev 2018;98:477-504. doi:10.1152/physrev.00039.2016.

[53] Dantzer R, Konsman JP, Bluthé RM, Kelley KW. Neural and humoral pathways of communication from the immune system to the brain: parallel or convergent? Auton Neurosci 2000;85:60-65. doi:10.1016/S1566-0702(00)00220-4.

[54] Dantzer R, O'Connor JC, Freund GG, Johnson RW, Kelley KW. From inflammation to sickness and depression: when the immune system subjugates the brain. Nat Rev Neurosci 2008;9:46-56. doi:10.1038/nrn2297.

[55] Das M, Penn C, Martinez T, Mayilsamy K, McGill A, Wiling A, Mohapatra SS, Mohapatra S. COVID-19 neurotropism and implications for therapy. Neuroimmunology and Neuroinflammation 2020;2020. doi:10.20517/2347-8659.2020.36.

[56] Davido B, Seang S, Tubiana R, de Truchis P. Post-COVID-19 chronic symptoms: a postinfectious entity? Clin Microbiol Infect 2020. doi:10.1016/j.cmi.2020.07.028.

[57] Debnath M, Banerjee M, Berk M. Genetic gateways to COVID-19 infection: Implications for risk, severity, and outcomes. FASEB J 2020. doi:10.1096/fj.202001115R.

[58] Débora da Luz Scheffer AL. Exercise-induced immune system response: Anti-inflammatory status on peripheral and central organs. Biochim Biophys Acta Mol Basis Dis 2020;1866:165823. doi:10.1016/j.bbadis.2020.165823.

[59] Del Valle DM, Kim-Schulze S, Huang H-H, Beckmann ND, Nirenberg S, Wang B, Lavin Y, Swartz TH, Madduri D, Stock A, Marron TU, Xie H, Patel M, Tuballes K, Van Oekelen O, Rahman A, Kovatch P, Aberg JA, Schadt E, Jagannath S, Mazumdar M, Charney AW, Firpo-Betancourt A, Mendu DR, Jhang J, Reich D, Sigel K, Cordon-Cardo C, Feldmann M, Parekh S, Merad M, Gnjatic S. An inflammatory cytokine signature predicts COVID-19 severity and survival. Nat Med 2020. doi:10.1038/s41591-020-1051-9.

[60] Dennis A, Wamil M, Kapur S, Alberts J, Badley AD, Decker GA, Rizza SA, Banerjee R, Banerjee A, On behalf of the COVERSCAN study investigators. Multi-organ impairment in low-risk individuals with long COVID. medRxiv 2020:2020.10.14.20212555. doi:10.1101/2020.10.14.20212555.

[61] Desforges M, Le Coupanec A, Dubeau P, Bourgouin A, Lajoie L, Dubé M, Talbot PJ. Human Coronaviruses and Other Respiratory Viruses: Underestimated Opportunistic Pathogens of the Central Nervous System? Viruses 2019;12:14. doi:10.3390/v12010014.

[62] Ding H, Yin S, Cheng Y, Cai Y, Huang W, Deng W. Neurologic manifestations of nonhospitalized patients with COVID-19 in Wuhan, China. MedComm 2020;1:253-256. doi:10.1002/mco2.13.

[63] DosSantos MF, Devalle S, Aran V, Capra D, Roque NR, de Mattos Coelho-Aguiar J, de Sampaio e 
Spohr TCL, Subilhaga JG, Pereira CM, Meira ID, Filho PNS, Moura-Neto V. Neuromechanisms of SARS-CoV-2: A Review. Front Neuroanat 2020;14. doi:10.3389/fnana.2020.00037.

[64] Dweck MR, Bularga A, Hahn RT, Bing R, Lee KK, Chapman AR, White A, Salvo GD, Sade LE, Pearce K, Newby DE, Popescu BA, Donal E, Cosyns B, Edvardsen T, Mills NL, Haugaa K. Global evaluation of echocardiography in patients with COVID-19. Eur Heart J Cardiovasc Imaging 2020;21. doi:10.1093/ehjci/jeaa178.

[65] Ehrenfeld M, Tincani A, Andreoli L, Cattalini M, Greenbaum A, Kanduc D, Alijotas-Reig J, Zinserling V, Semenova N, Amital H, Shoenfeld Y. Covid-19 and autoimmunity. Autoimmunity Reviews 2020;19:102597. doi:10.1016/j.autrev.2020.102597.

[66] El Baba R, Herbein G. Management of epigenomic networks entailed in coronavirus infections and COVID-19. Clin Epigenetics 2020;12:118. doi:10.1186/s13148-020-00912-7.

[67] Elmarakby AA, Sullivan JC. Relationship between oxidative stress and inflammatory cytokines in diabetic nephropathy. Cardiovasc Ther 2012;30:49-59. doi:10.1111/j.1755-5922.2010.00218.x.

[68] England J. Parainfectious neuropathies. Journal of the Neurological Sciences 2019;405:22. doi:10.1016/j.jns.2019.10.060.

[69] Eshak N, Abdelnabi M, Ball S, Elgwairi E, Creed K, Test V, Nugent K. Dysautonomia: An Overlooked Neurological Manifestation in a Critically ill COVID-19 Patient. The American Journal of the Medical Sciences 2020. doi:10.1016/j.amjms.2020.07.022.

[70] Evidence for a cytokine model of cognitive function. Neurosci Biobehav Rev 2009;33:355-366. doi:10.1016/j.neubiorev.2008.10.005.

[71] Fann MJ, Patterson PH. Neuropoietic cytokines and activin A differentially regulate the phenotype of cultured sympathetic neurons. Proc Natl Acad Sci U S A 1994;91:43-47. doi:10.1073/pnas.91.1.43.

[72] Fenini G, Grossi S, Gehrke S, Beer H-D, Satoh TK, Contassot E, French LE. The p38 Mitogen-Activated Protein Kinase Critically Regulates Human Keratinocyte Inflammasome Activation. J Invest Dermatol 2018;138:1380-1390. doi:10.1016/j.jid.2017.10.037.

[73] Fenrich M, Mrdenovic S, Balog M, Tomic S, Zjalic M, Roncevic A, Mandic D, Debeljak Z, Heffer M. SARS-CoV-2 Dissemination Through Peripheral Nerves Explains Multiple Organ Injury. Front Cell Neurosci 2020;14. doi:10.3389/fncel.2020.00229.

[74] Ferreira SH, Lorenzetti BB, Poole S. Bradykinin initiates cytokine-mediated inflammatory hyperalgesia. Br J Pharmacol 1993;110. doi:10.1111/j.1476-5381.1993.tb13946.x.

[75] Fever, fever patterns and diseases called "fever" - A review. J Infect Public Health 2011;4:108-124. doi:10.1016/j.jiph.2011.05.002.

[76] Finnell JE, Lombard CM, Melson MN, Singh NP, Nagarkatti M, Nagarkatti P, Fadel JR, Wood CS, Wood SK. The protective effects of resveratrol on social stress-induced cytokine release and depressive-like behavior. Brain Behav Immun 2017;59. doi:10.1016/j.bbi.2016.08.019.

[77] Fischer CP. Interleukin-6 in acute exercise and training: what is the biological relevance? Exerc 
Immunol Rev 2006;12. Available: https://pubmed.ncbi.nIm.nih.gov/17201070/. Accessed 22 Aug 2020.

[78] Fischer CP. Interleukin-6 in acute exercise and training: what is the biological relevance. Exerc Immunol Rev 2006;12:41. Available: http://eir-isei.de/2006/eir-2006-003-article.pdf\#page=4.

[79] Fluge $\varnothing$, Mella O, Bruland O, Risa K, Dyrstad SE, Alme K, Rekeland IG, Sapkota D, Røsland GV, Fosså A, Ktoridou-Valen I, Lunde S, Sørland K, Lien K, Herder I, Thürmer H, Gotaas ME, Baranowska KA, Louis M L, Schäfer C, McCann A, Sommerfelt K, Helgeland L, Ueland PM, Dahl O, Tronstad KJ. Metabolic profiling indicates impaired pyruvate dehydrogenase function in myalgic encephalopathy/chronic fatigue syndrome. JCI Insight 2017;1. doi:10.1172/jci.insight.89376.

[80] F. Pérez-Bartolomé JS-Q. Ocular manifestations of SARS-CoV-2: Literature review. Archivos De La Sociedad Espan ola De Oftalmologi'a n.d. doi:10.1016/j.oftale.2020.07.003.

[81] Frank-Cannon TC, Alto LT, McAlpine FE, Tansey MG. Does neuroinflammation fan the flame in neurodegenerative diseases? Mol Neurodegener 2009;4:1-13. doi:10.1186/1750-1326-4-47.

[82] Furman D, Campisi J, Verdin E, Carrera-Bastos P, Targ S, Franceschi C, Ferrucci L, Gilroy DW, Fasano A, Miller GW, Miller AH, Mantovani A, Weyand CM, Barzilai N, Goronzy JJ, Rando TA, Effros RB, Lucia A, Kleinstreuer N, Slavich GM. Chronic inflammation in the etiology of disease across the life span. Nat Med 2019;25:1822-1832. doi:10.1038/s41591-019-0675-0.

[83] Gaebler C, Wang Z, Lorenzi JCC, Muecksch F, Finkin S, Tokuyama M, Ladinsky M, Cho A, Jankovic M, Schaefer-Babajew D, Oliveira TY, Cipolla M, Viant C, Barnes CO, Hurley A, Turroja M, Gordon K, Millard KG, Ramos V, Schmidt F, Weisblum Y, Jha D, Tankelevich M, Yee J, Shimeliovich I, Robbiani DF, Zhao Z, Gazumyan A, Hatziioannou T, Bjorkman PJ, Mehandru S, Bieniasz PD, Caskey M, Nussenzweig MC. Evolution of Antibody Immunity to SARS-CoV-2. Cold Spring Harbor Laboratory 2020:2020.11.03.367391. doi:10.1101/2020.11.03.367391.

[84] Galeotti C, Bayry J. Autoimmune and inflammatory diseases following COVID-19. Nat Rev Rheumatol 2020;16:413-414. doi:10.1038/s41584-020-0448-7.

[85] Gao J. Correlation between anxiety-depression status and cytokines in diarrhea-predominant irritable bowel syndrome. Exp Ther Med 2013;6:93. doi:10.3892/etm.2013.1101.

[86] Garrigues E, Janvier P, Kherabi Y, Le Bot A, Hamon A, Gouze H, Doucet L, Berkani S, Oliosi E, Mallart E, Corre F, Zarrouk V, Moyer J-D, Galy A, Honsel V, Fantin B, Nguyen Y. Post-discharge persistent symptoms and health-related quality of life after hospitalization for COVID-19. J Infect 2020. doi:10.1016/j.jinf.2020.08.029.

[87] Garvin MR, Alvarez C, Izaak Miller J, Prates ET, Walker AM, Kirtley Amos B, Mast AE, Justice A, Aronow B, Jacobson D. A mechanistic model and therapeutic interventions for COVID-19 involving a RAS-mediated bradykinin storm. 2020. doi:10.7554/eLife.59177.

[88] Gatti P, Ilamathi HS, Todkar K, Germain M. Mitochondria Targeted Viral Replication and Survival Strategies-Prospective on SARS-CoV-2. Front Pharmacol 2020;11. doi:10.3389/fphar.2020.578599.

[89] Gemmati D, Bramanti B, Serino ML, Secchiero P, Zauli G, Tisato V. COVID-19 and Individual Genetic Susceptibility/Receptivity: Role of ACE1/ACE2 Genes, Immunity, Inflammation and Coagulation. 
Might the Double X-chromosome in Females Be Protective against SARS-CoV-2 Compared to the Single X-Chromosome in Males? Int J Mol Sci 2020;21. doi:10.3390/ijms21103474.

[90] Godbout JP, Chen J, Abraham J, Richwine AF, Berg BM, Kelley KW, Johnson RW. Exaggerated neuroinflammation and sickness behavior in aged mice after activation of the peripheral innate immune system. The FASEB Journal 2005;19:1329-1331. doi:10.1096/fj.05-3776fje.

[91] Gori A, Leone F, Loffredo L, Cinicola BL, Brindisi G, De Castro G, Spalice A, Duse M, Zicari AM. COVID-19-Related Anosmia: The Olfactory Pathway Hypothesis and Early Intervention. Front Neurol 2020;11. doi:10.3389/fneur.2020.00956.

[92] Grimes JM, Grimes KV. p38 MAPK inhibition: A promising therapeutic approach for COVID-19. J Mol Cell Cardiol 2020;144:63-65. doi:10.1016/j.yjmcc.2020.05.007.

[93] Haddad EB, Fox AJ, Rousell J, Burgess G, Mclntyre P, Barnes PJ, Chung KF. Post-transcriptional regulation of bradykinin $B 1$ and $B 2$ receptor gene expression in human lung fibroblasts by tumor necrosis factor-alpha: modulation by dexamethasone. Mol Pharmacol 2000;57. Available: https://pubmed.ncbi.nlm.nih.gov/10825382/. Accessed 9 Sep 2020.

[94] Hadjadj J, Yatim N, Barnabei L, Corneau A, Boussier J, Smith N, Péré H, Charbit B, Bondet V, Chenevier-Gobeaux C, Breillat $P$, Carlier N, Gauzit R, Morbieu C, Pène F, Marin N, Roche N, Szwebel TA, Merkling SH, Treluyer JM, Veyer D, Mouthon L, Blanc C, Tharaux PL, Rozenberg F, Fischer A, Duffy $D$, Rieux-Laucat $F$, Kernéis $S$, Terrier B. Impaired type I interferon activity and inflammatory responses in severe COVID-19 patients. Science 2020;369. doi:10.1126/science.abc6027.

[95] Hasselbalch HC. The role of cytokines in the initiation and progression of myelofibrosis. Cytokine Growth Factor Rev 2013;24. doi:10.1016/j.cytogfr.2013.01.004.

[96] Hayashi R, Yamashita N, Matsui S, Fujita T, Araya J, Sassa K, Arai N, Yoshida Y, Kashii T, Maruyama M, Sugiyama E, Kobayashi M. Bradykinin stimulates IL-6 and IL-8 production by human lung fibroblasts through ERK- and p38 MAPK-dependent mechanisms. Eur Respir J 2000;16:452-458. doi:10.1034/j.1399-3003.2000.016003452.x.

[97] Hedrich CM, Crispin JC, Tsokos GC. Epigenetic regulation of cytokine expression in systemic lupus erythematosus with special focus on T cells. Autoimmunity 2014;47. doi:10.3109/08916934.2013.801462.

[98] Herold T, Jurinovic V, Arnreich C, Lipworth BJ, Hellmuth JC, von Bergwelt-Baildon M, Klein M, Weinberger T. Elevated levels of IL- 6 and CRP predict the need for mechanical ventilation in COVID-19. Journal of Allergy and Clinical Immunology 2020;146:128-136.e4. doi:10.1016/j.jaci.2020.05.008.

[99] Hirano T, Murakami M. COVID-19: A New Virus, but a Familiar Receptor and Cytokine Release Syndrome. Immunity 2020;52:731-733. doi:10.1016/j.immuni.2020.04.003.

[100] Hoffmann SC, Stanley EM, Cox ED, DiMercurio BS, Koziol DE, Harlan DM, Kirk AD, Blair PJ. Ethnicity greatly influences cytokine gene polymorphism distribution. Am J Transplant 2002;2. doi:10.1034/j.1600-6143.2002.20611.x.

[101] Hosseini S, Wilk E, Michaelsen-Preusse K, Gerhauser I, Baumgärtner W, Geffers R, Schughart K, 
Korte M. Long-Term Neuroinflammation Induced by Influenza A Virus Infection and the Impact on Hippocampal Neuron Morphology and Function. J Neurosci 2018;38:3060-3080.

doi:10.1523/JNEUROSCI.1740-17.2018.

[102] Hou R, Garner M, Holmes C, Osmond C, Teeling J, Lau L, Baldwin DS. Peripheral inflammatory cytokines and immune balance in Generalised Anxiety Disorder: Case-controlled study. Brain Behav Immun 2017;62:212-218. doi:10.1016/j.bbi.2017.01.021.

[103] Huang C, Wang Y, Li X, Ren L, Zhao J, Hu Y, Zhang L, Fan G, Xu J, Gu X, Cheng Z, Yu T, Xia J, Wei Y, Wu W, Xie X, Yin W, Li H, Liu M, Xiao Y, Gao H, Guo L, Xie J, Wang G, Jiang R, Gao Z, Jin Q, Wang J, Cao B. Clinical features of patients infected with 2019 novel coronavirus in Wuhan, China. Lancet 2020;395. doi:10.1016/S0140-6736(20)30183-5.

[104] Huang Y, Tan C, Wu J, Chen M, Wang Z, Luo L, Zhou X, Liu X, Huang X, Yuan S, Chen C, Gao F, Huang J, Shan H, Liu J. Impact of coronavirus disease 2019 on pulmonary function in early convalescence phase. Respir Res 2020;21. doi:10.1186/s12931-020-01429-6.

[105] Hung AL, Lim M, Doshi TL. Targeting cytokines for treatment of neuropathic pain. Scandinavian journal of pain 2017;17. doi:10.1016/j.sjpain.2017.08.002.

[106] Huth TK, Staines D, Marshall-Gradisnik S. ERK1/2, MEK1/2 and p38 downstream signalling molecules impaired in CD56 dim CD16+ and CD56 bright CD16 dim/- natural killer cells in Chronic Fatigue Syndrome/Myalgic Encephalomyelitis patients. J Transl Med 2016;14. doi:10.1186/s12967-016-0859-z.

[107] Immune system disruption. n.d. Available: http://stanmed.stanford.edu/2014fall/immune-system-disruption.html. Accessed 23 Aug 2020.

[108] Islam MF, Cotler J, Jason LA. Post-viral fatigue and COVID-19: lessons from past epidemics. Fatigue: Biomedicine, Health \& Behavior 2020;8:61-69. doi:10.1080/21641846.2020.1778227.

[109] Jennifer C. Felger AHM. Cytokine Effects on the Basal Ganglia and Dopamine Function: the Subcortical Source of Inflammatory Malaise. Front Neuroendocrinol 2012;33:315. doi:10.1016/j.yfrne.2012.09.003.

[110] Josef Finsterer WG. Disorders of the lower cranial nerves. J Neurosci Rural Pract 2015;6:377. doi:10.4103/0976-3147.158768.

[111] Kamal D. Moudgil DC. Cytokines in Autoimmunity: Role in Induction, Regulation, and Treatment. J Interferon Cytokine Res 2011;31:695. doi:10.1089/jir.2011.0065.

[112] Kaptoge S, White IR, Thompson SG, Wood AM, Lewington S, Lowe GDO, Danesh J, Kostis JB, Wilson AC, Folsom AR, Others. Associations of plasma fibrinogen levels with established cardiovascular disease risk factors, inflammatory markers, and other characteristics: individual participant meta-analysis of 154,211 adults in 31 prospective studies. Am J Epidemiol 2007;166:867-879. Available:

https://experts.umn.edu/en/publications/associations-of-plasma-fibrinogen-levels-with-establishe d-cardiov.

[113] Kaur C, Rathnasamy G, Ling EA. Biology of Microglia in the Developing Brain. J Neuropathol Exp 
Neurol 2017;76. doi:10.1093/jnen/nlx056.

[114] Keller C, Steensberg A, Hansen AK, Fischer CP, Plomgaard P, Pedersen BK. Effect of exercise, training, and glycogen availability on IL-6 receptor expression in human skeletal muscle. J Appl Physiol 2005;99. doi:10.1152/japplphysiol.00590.2005.

[115] Kenney MJ, Ganta CK. Autonomic Nervous System and Immune System Interactions. Comprehensive Physiology 2014:1177-1200. doi:10.1002/cphy.c130051.

[116] Khairova RA, Machado-Vieira R, Du J, Manji HK. A potential role for pro-inflammatory cytokines in regulating synaptic plasticity in major depressive disorder. Int J Neuropsychopharmacol 2009;12:561-578. doi:10.1017/S1461145709009924.

[117] Khan MA-A-K, Abul Bashar Mir Md. SARS-CoV-2 proteins exploit host's genetic and epigenetic mediators for the annexation of key host signaling pathways that confers its immune evasion and disease pathophysiology. n.d. doi:10.1101/2020.05.06.050260.

[118] Kim H-K, Konishi M, Takahashi M, Tabata H, Endo N, Numao S, Lee S-K, Kim Y-H, Suzuki K, Sakamoto S. Effects of Acute Endurance Exercise Performed in the Morning and Evening on Inflammatory Cytokine and Metabolic Hormone Responses. PLoS One 2015;10. doi:10.1371/journal.pone.0137567.

[119] Klok FA, Kruip MJHA, van der Meer NJM, Arbous MS, Gommers DAMPJ, Kant KM, Kaptein FHJ, van Paassen J, Stals MAM, Huisman MV, Endeman H. Incidence of thrombotic complications in critically ill ICU patients with COVID-19. Thromb Res 2020;191:145-147. doi:10.1016/j.thromres.2020.04.013.

[120] Kluger MJ. Fever: role of pyrogens and cryogens. Physiol Rev 1991;71:93-127. doi:10.1152/physrev.1991.71.1.93.

[121] Konstantinos Paschos MJA. Epigenetic reprogramming of host genes in viral and microbial pathogenesis. Trends Microbiol 2010;18:439. doi:10.1016/j.tim.2010.07.003.

[122] Kronfol Z. Cytokines and the Brain: Implications for Clinical Psychiatry. American Journal of Psychiatry 2000;157:683-694. doi:10.1176/appi.ajp.157.5.683.

[123] Lam MH-B, Wing Y-K, Yu MW-M, Leung C-M, Ma RCW, Kong APS, So WY, Fong SY-Y, Lam S-P. Mental Morbidities and Chronic Fatigue in Severe Acute Respiratory Syndrome Survivors:

Long-term Follow-up. Arch Intern Med 2009;169:2142-2147. doi:10.1001/archinternmed.2009.384.

[124] Landers-Ramos RQ, Jenkins NT, Spangenburg EE, Hagberg JM, Prior SJ. Circulating angiogenic and inflammatory cytokine responses to acute aerobic exercise in trained and sedentary young men. Eur J Appl Physiol 2014;114:1377. doi:10.1007/s00421-014-2861-6.

[125] Langjahr M, Schubert AL, Sommer C, Üçeyler N. Increased pro-inflammatory cytokine gene expression in peripheral blood mononuclear cells of patients with polyneuropathies. J Neurol 2018;265. doi:10.1007/s00415-018-8748-4.

[126] Lavi E, Cong L. Type I astrocytes and microglia induce a cytokine response in an encephalitic 
murine coronavirus infection. Exp Mol Pathol 2020;115. doi:10.1016/j.yexmp.2020.104474.

[127] Lechien JR, Chiesa-Estomba CM, De Siati DR, Horoi M, Le Bon SD, Rodriguez A, Dequanter D, Blecic S, El Afia F, Distinguin L, Chekkoury-Idrissi Y, Hans S, Delgado IL, Calvo-Henriquez C, Lavigne $P$, Falanga C, Barillari MR, Cammaroto G, Khalife M, Leich P, Souchay C, Rossi C, Journe F, Hsieh J, Edjlali M, Carlier R, Ris L, Lovato A, De Filippis C, Coppee F, Fakhry N, Ayad T, Saussez S. Olfactory and gustatory dysfunctions as a clinical presentation of mild-to-moderate forms of the coronavirus disease (COVID-19): a multicenter European study. Eur Arch Otorhinolaryngol 2020;277. doi:10.1007/s00405-020-05965-1.

[128] Lee DW, Gardner R, Porter DL, Louis CU, Ahmed N, Jensen M, Grupp SA, Mackall CL. Current concepts in the diagnosis and management of cytokine release syndrome. Blood 2014;124:188-195. doi:10.1182/blood-2014-05-552729.

[129] Lei X, Dong X, Ma R, Wang W, Xiao X, Tian Z, Wang C, Wang Y, Li L, Ren L, Guo F, Zhao Z, Zhou Z, Xiang $Z$, Wang J. Activation and evasion of type I interferon responses by SARS-CoV-2. Nat Commun 2020;11:3810. doi:10.1038/s41467-020-17665-9.

[130] Leow MK, Kwek DS, Ng AW, Ong KC, Kaw GJ, Lee LS. Hypocortisolism in survivors of severe acute respiratory syndrome (SARS). Clin Endocrinol 2005;63. doi:10.1111/j.1365-2265.2005.02325.x.

[131] Li L, Mao S, Wang J, Ding X, Zen JY. Viral infection and neurological disorders - potential role of extracellular nucleotides in neuroinflammation. ExRNA 2019;1:1-5. doi:10.1186/s41544-019-0031-z.

[132] Lima M, Siokas V, Aloizou AM, Liampas I, Mentis AA, Tsouris Z, Papadimitriou A, Mitsias PD, Tsatsakis A, Bogdanos DP, Baloyannis SJ, Dardiotis E. Unraveling the Possible Routes of SARS-COV-2 Invasion into the Central Nervous System. Curr Treat Options Neurol 2020;22. doi:10.1007/s11940-020-00647-z.

[133] Lin YS, Lin CF, Fang YT, Kuo YM, Liao PC, Yeh TM, Hwa KY, Shieh CCK, Yen JH, Wang HJ, Su IJ, Lei $\mathrm{HY}$. Antibody to severe acute respiratory syndrome (SARS)-associated coronavirus spike protein domain 2 cross-reacts with lung epithelial cells and causes cytotoxicity. Clin Exp Immunol 2005;141:500-508. doi:10.1111/j.1365-2249.2005.02864.x.

[134] Liotta EM, Batra A, Clark JR, Shlobin NA, Hoffman SC, Orban ZS, Koralnik IJ. Frequent neurologic manifestations and encephalopathy-associated morbidity in Covid-19 patients. Ann Clin Transl Neurol 2020. doi:10.1002/acn3.51210.

[135] Liu T, Zhang L, Joo D, Sun SC. NF- $\kappa$ B signaling in inflammation. Signal transduction and targeted therapy 2017;2. doi:10.1038/sigtrans.2017.23.

[136] Living with Covid19. n.d. Available: https://evidence.nihr.ac.uk/themedreview/living-with-covid19/. Accessed 26 Oct 2020.

[137] Low levels of circulating inflammatory cytokines-Do they affect human brain functions? Brain Behav Immun 2002;16:525-532. doi:10.1016/S0889-1591(02)00004-1.

[138] de Lucena TMC, da Silva Santos AF, de Lima BR, de Albuquerque Borborema ME, de Azevêdo Silva J. Mechanism of inflammatory response in associated comorbidities in COVID-19. Diabetes 
Metab Syndr 2020;14:597. doi:10.1016/j.dsx.2020.05.025.

[139] Magrinelli F, Briani C, Romano M, Ruggero S, Toffanin E, Triolo G, Peter GC, Praitano M, Lauriola MF, Zanette G, Tamburin S. The Association between Serum Cytokines and Damage to Large and Small Nerve Fibers in Diabetic Peripheral Neuropathy. Journal of diabetes research 2015;2015. doi:10.1155/2015/547834.

[140] Majde JA. Neuroinflammation resulting from covert brain invasion by common viruses - a potential role in local and global neurodegeneration. Med Hypotheses 2010;75. doi:10.1016/j.mehy.2010.02.023.

[141] Manne BK, Denorme F, Middleton EA, Portier I, Rowley JW, Stubben C, Petrey AC, Tolley ND, Guo L, Cody M, Weyrich AS, Yost CC, Rondina MT, Campbell RA. Platelet gene expression and function in patients with COVID-19. Blood 2020;136. doi:10.1182/blood.2020007214.

[142] Marni N. Silverman EMS. Glucocorticoid regulation of inflammation and its behavioral and metabolic correlates: from HPA axis to glucocorticoid receptor dysfunction. Ann N Y Acad Sci 2012;1261:55. doi:10.1111/j.1749-6632.2012.06633.x.

[143] Marsland AL, Walsh C, Lockwood K, John-Henderson NA. The effects of acute psychological stress on circulating and stimulated inflammatory markers: A systematic review and meta-analysis. Brain Behav Immun 2017;64:208. doi:10.1016/j.bbi.2017.01.011.

[144] Martínez-Reyes I, Chandel NS. Mitochondrial TCA cycle metabolites control physiology and disease. Nat Commun 2020;11:1-11. doi:10.1038/s41467-019-13668-3.

[145] Matschke J, Lütgehetmann M, Hagel C, Sperhake JP, Schröder AS, Edler C, Mushumba H, Fitzek A, Allweiss L, Dandri M, Dottermusch M, Heinemann A, Pfefferle S, Schwabenland M, Magruder DS, Bonn S, Prinz M, Gerloff C, Püschel K, Krasemann S, Aepfelbacher M, Glatzel M. Neuropathology of patients with COVID-19 in Germany: a post-mortem case series. The Lancet Neurology 2020. doi:10.1016/s1474-4422(20)30308-2.

[146] Maurer M, Bader M, Bas M, Bossi F, Cicardi M, Cugno M, Howarth P, Kaplan A, Kojda G, Leeb-Lundberg F, Lötvall J, Magerl M. New topics in bradykinin research. Allergy 2011;66:1397-1406. doi:10.1111/j.1398-9995.2011.02686.x.

[147] Mazzone R, Zwergel C, Artico M, Taurone S, Ralli M, Greco A, Mai A. The emerging role of epigenetics in human autoimmune disorders. Clin Epigenetics 2019;11. doi:10.1186/s13148-019-0632-2.

[148] McIntyre TM. Inflammatory Cytokines and Thrombosis. Blood 2012;120:SCl-44-SCI-44. doi:10.1182/blood.V120.21.SCl-44.SCl-44.

[149] Meftahi GH, Jangravi Z, Sahraei H, Bahari Z. The possible pathophysiology mechanism of cytokine storm in elderly adults with COVID-19 infection: the contribution of "inflame-aging." Inflamm Res 2020;69:825-839. doi:10.1007/s00011-020-01372-8.

[150] Mehta P, McAuley DF, Brown M, Sanchez E, Tattersall RS, Manson JJ. COVID-19: consider cytokine storm syndromes and immunosuppression. The Lancet 2020;395:1033-1034. 
doi:10.1016/s0140-6736(20)30628-0.

[151] Merad M, Martin JC. Author Correction: Pathological inflammation in patients with COVID-19: a key role for monocytes and macrophages. Nat Rev Immunol 2020;20:448. doi:10.1038/s41577-020-0353-y.

[152] Merad M, Martin JC. Pathological inflammation in patients with COVID-19: a key role for monocytes and macrophages. Nat Rev Immunol 2020;20. doi:10.1038/s41577-020-0331-4.

[153] Miller AH, Haroon E, Raison CL, Felger JC. Cytokine Targets in the Brain: Impact on Neurotransmitters and Neurocircuits. Depress Anxiety 2013;30:297. doi:10.1002/da.22084.

[154] Miller AH, Jones JF, Drake DF, Tian H, Unger ER, Pagnoni G. Decreased Basal Ganglia Activation in Subjects with Chronic Fatigue Syndrome: Association with Symptoms of Fatigue. PLoS One 2014;9. doi:10.1371/journal.pone.0098156.

[155] Miller RJ, Jung H, Bhangoo SK, White FA. Cytokine and Chemokine Regulation of Sensory Neuron Function. Sensory Nerves. Springer, Berlin, Heidelberg, 2009. pp. 417-449. doi:10.1007/978-3-540-79090-7_12.

[156] Missiroli S, Genovese I, Perrone M, Vezzani B, Vitto VAM, Giorgi C. The Role of Mitochondria in Inflammation: From Cancer to Neurodegenerative Disorders. Journal of Clinical Medicine 2020;9:740. doi:10.3390/jcm9030740.

[157] Mizutani T, Fukushi S, Saijo M, Kurane I, Morikawa S. Phosphorylation of p38 MAPK and its downstream targets in SARS coronavirus-infected cells. Biochem Biophys Res Commun 2004;319:1228-1234. doi:10.1016/j.bbrc.2004.05.107.

[158] Mogensen TH, Paludan SR. Molecular Pathways in Virus-Induced Cytokine Production. Microbiology and Molecular Biology Reviews 2001;65:131-150. doi:10.1128/mmbr.65.1.131-150.2001.

[159] Mohammadi S, Moosaie F, Aarabi MH. Understanding the Immunologic Characteristics of Neurologic Manifestations of SARS-CoV-2 and Potential Immunological Mechanisms. Mol Neurobiol 2020. doi:10.1007/s12035-020-02094-y.

[160] Montoya JG, Holmes TH, Anderson JN, Maecker HT, Rosenberg-Hasson Y, Valencia IJ, Chu L, Younger JW, Tato CM, Davis MM. Cytokine signature associated with disease severity in chronic fatigue syndrome patients. Proc Natl Acad Sci U S A 2017;114:E7150-E7158. doi:10.1073/pnas.1710519114.

[161] Moore JB, June CH. Cytokine release syndrome in severe COVID-19. Science 2020;368:473-474. doi:10.1126/science.abb8925.

[162] Morris G, Berk M, Walder K, Maes M. Central pathways causing fatigue in neuro-inflammatory and autoimmune illnesses. BMC Med 2015;13. doi:10.1186/s12916-014-0259-2.

[163] Morris G, Maes M. Increased nuclear factor- $\kappa$ B and loss of p53 are key mechanisms in Myalgic Encephalomyelitis/chronic fatigue syndrome (ME/CFS). Med Hypotheses 2012;79:607-613. doi:10.1016/j.mehy.2012.07.034. 
[164] Morris G, Maes M. Mitochondrial dysfunctions in Myalgic Encephalomyelitis / chronic fatigue syndrome explained by activated immuno-inflammatory, oxidative and nitrosative stress pathways. Metab Brain Dis 2013;29:19-36. doi:10.1007/s11011-013-9435-x.

[165] Morris G, Maes M, Berk M, Puri BK. Myalgic encephalomyelitis or chronic fatigue syndrome: how could the illness develop? Metab Brain Dis 2019;34:385-415. doi:10.1007/s11011-019-0388-6.

[166] Mo X, Jian W, Su Z, Chen M, Peng H, Peng P, Lei C, Chen R, Zhong N, Li S. Abnormal pulmonary function in COVID-19 patients at time of hospital discharge. Eur Respir J 2020;55.

doi:10.1183/13993003.01217-2020.

[167] Murta V, Villarreal A, Ramos AJ. SARS-CoV-2 Impact on the Central Nervous System: Are Astrocytes and Microglia Main Players or Merely Bystanders? 2020. doi:10.20944/preprints202006.0319.v1.

[168] Nahirnyj A, Livne-Bar I, Guo X, Sivak JM. ROS Detoxification and Proinflammatory Cytokines Are Linked by p38 MAPK Signaling in a Model of Mature Astrocyte Activation. PLoS One 2013;8:e83049. doi:10.1371/journal.pone.0083049.

[169] Najem MY, Couturaud F, Lemarié CA. Cytokine and chemokine regulation of venous thromboembolism. J Thromb Haemost 2020;18:1009-1019. doi:10.1111/jth.14759.

[170] Najjar S, Pearlman DM, Alper K, Najjar A, Devinsky O. Neuroinflammation and psychiatric illness. J Neuroinflammation 2013;10:1-24. doi:10.1186/1742-2094-10-43.

[171] Netea MG, Kullberg BJ, Van der Meer JWM. Circulating Cytokines as Mediators of Fever. Clin Infect Dis 2000;31:S178-S184. doi:10.1086/317513.

[172] Neuronal differentiation factors/cytokines and synaptic plasticity. Cell 1993;72:123-137. doi:10.1016/S0092-8674(05)80032-7.

[173] Niraula A, Sheridan JF, Godbout JP. Microglia Priming with Aging and Stress. Neuropsychopharmacology 2017;42. doi:10.1038/npp.2016.185.

[174] Okamoto LE, Raj SR, Gamboa A, Shibao CA, Arnold AC, Garland EM, Black BK, Farley G, Diedrich $A$, Biaggioni I. Sympathetic activation is associated with increased IL-6, but not CRP in the absence of obesity: lessons from postural tachycardia syndrome and obesity. American Journal of Physiology-Heart and Circulatory Physiology 2015;309:H2098-H2107. doi:10.1152/ajpheart.00409.2015.

[175] Oliveira-Pinto AV, Santos RM, Coutinho RA, Oliveira LM, Santos GB, Alho AT, Leite RE, Farfel JM, Suemoto CK, Grinberg LT, Pasqualucci CA, Jacob-Filho W, Lent R. Sexual dimorphism in the human olfactory bulb: females have more neurons and glial cells than males. PLoS One 2014;9. doi:10.1371/journal.pone.0111733.

[176] Paalani M, Lee JW, Haddad E, Tonstad S. Determinants of Inflammatory Markers in a Bi-ethnic Population. Ethn Dis 2011;21:142. Available:

https://www.ncbi.nlm.nih.gov/pmc/articles/PMC3427005/. Accessed 22 Aug 2020.

[177] Palaiodimos L, Kokkinidis DG, Li W, Karamanis D, Ognibene J, Arora S, Southern WN, Mantzoros 
CS. Severe obesity, increasing age and male sex are independently associated with worse in-hospital outcomes, and higher in-hospital mortality, in a cohort of patients with COVID-19 in the Bronx, New York. Metabolism 2020;108:154262. doi:10.1016/j.metabol.2020.154262.

[178] Pal R. COVID-19, hypothalamo-pituitary-adrenal axis and clinical implications. Endocrine n.d.:1. doi:10.1007/s12020-020-02325-1.

[179] Paniz-Mondolfi A, Bryce C, Grimes Z, Gordon RE, Reidy J, Lednicky J, Sordillo EM, Fowkes M. Central nervous system involvement by severe acute respiratory syndrome coronavirus-2 (SARS-CoV-2). Journal of Medical Virology 2020;92:699-702. doi:10.1002/jmv.25915.

[180] Piraino B, Vollmer-Conna U, Lloyd AR. Genetic associations of fatigue and other symptom domains of the acute sickness response to infection. Brain Behav Immun 2012;26:552-558. doi:10.1016/j.bbi.2011.12.009.

[181] Platt MP, Agalliu D, Cutforth T. Hello from the Other Side: How Autoantibodies Circumvent the Blood-Brain Barrier in Autoimmune Encephalitis. Front Immunol 2017;8. doi:10.3389/fimmu.2017.00442.

[182] Pruimboom L. Methylation Pathways and SARS-CoV-2 Lung Infiltration and Cell Membrane-Virus Fusion Are Both Subject to Epigenetics. Front Cell Infect Microbiol 2020;10:290. doi:10.3389/fcimb.2020.00290.

[183] Püntener U, Booth SG, Hugh Perry V, Teeling JL. Long-term impact of systemic bacterial infection on the cerebral vasculature and microglia. J Neuroinflammation 2012;9:146. doi:10.1186/1742-2094-9-146.

[184] Qin C, Zhou L, Hu Z, Zhang S, Yang S, Tao Y, Xie C, Ma K, Shang K, Wang W, Tian D-S. Dysregulation of Immune Response in Patients With Coronavirus 2019 (COVID-19) in Wuhan, China. Clin Infect Dis 2020;71:762-768. doi:10.1093/cid/ciaa248.

[185] Rakotoarivelo V, Lacraz G, Mayhue M, Brown C, Rottembourg D, Fradette J, llangumaran S, Menendez A, Langlois M-F, Ramanathan S. Inflammatory Cytokine Profiles in Visceral and Subcutaneous Adipose Tissues of Obese Patients Undergoing Bariatric Surgery Reveal Lack of Correlation With Obesity or Diabetes. EBioMedicine 2018;30:237-247. doi:10.1016/j.ebiom.2018.03.004.

[186] Rana SV, Sharma S, Sinha SK, Parsad KK, Malik A, Singh K. Pro-inflammatory and anti-inflammatory cytokine response in diarrhoea-predominant Irritable bowel syndrome patients. Trop Gastroenterol 2013;33:251-256. doi:10.7869/tg.2012.66.

[187] Randeria SN, Thomson GJA, Nell TA, Roberts T, Pretorius E. Inflammatory cytokines in type 2 diabetes mellitus as facilitators of hypercoagulation and abnormal clot formation. Cardiovasc Diabetol 2019;18:1-15. doi:10.1186/s12933-019-0870-9.

[188] Rasa S, Nora-Krukle Z, Henning N, Eliassen E, Shikova E, Harrer T, Scheibenbogen C, Murovska M, Prusty BK. Chronic viral infections in myalgic encephalomyelitis/chronic fatigue syndrome (ME/CFS). J Transl Med 2018;16:1-25. doi:10.1186/s12967-018-1644-y.

[189] Reisinger EC, Fritzsche C, Krause R, Krejs GJ. Diarrhea caused by primarily non-gastrointestinal 
infections. Nat Clin Pract Gastroenterol Hepatol 2005;2. doi:10.1038/ncpgasthep0167.

[190] Resveratrol potentiates the effect of dexamethasone in rat model of acute lung inflammation. Int Immunopharmacol 2015;28:773-779. doi:10.1016/j.intimp.2015.07.038.

[191] Rivera MC, Mastronardi C, Silva-Aldana CT, Arcos-Burgos M, Lidbury BA. Myalgic Encephalomyelitis/Chronic Fatigue Syndrome: A Comprehensive Review. Diagnostics 2019;9. doi:10.3390/diagnostics9030091.

[192] Rivier C, Rivest S. Mechanisms Mediating the Effects of Cytokines on Neuroendocrine Functions in the Rat. Ciba Foundation Symposium 172 - Corticotropin-Releasing Factor 2007:204-225. doi:10.1002/9780470514368.ch10.

[193] Saha RN, Jana M, Pahan K. MAPK p38 Regulates Transcriptional Activity of NF- $\kappa$ B in Primary Human Astrocytes via Acetylation of p65. The Journal of Immunology 2007;179:7101-7109. doi:10.4049/jimmunol.179.10.7101.

[194] Saleh J, Peyssonnaux C, Singh KK, Edeas M. Mitochondria and microbiota dysfunction in COVID-19 pathogenesis. Mitochondrion 2020;54:1-7. doi:10.1016/j.mito.2020.06.008.

[195] Sarkar S, Malovic E, Harishchandra DS, Ghaisas S, Panicker N, Charli A, Palanisamy BN, Rokad D, Jin $\mathrm{H}$, Anantharam V, Kanthasamy A, Kanthasamy AG. Mitochondrial impairment in microglia amplifies NLRP3 inflammasome proinflammatory signaling in cell culture and animal models of Parkinson's disease. NPJ Parkinsons Dis 2017;3:30. doi:10.1038/s41531-017-0032-2.

[196] Sartor RB. Cytokines in intestinal inflammation: pathophysiological and clinical considerations. Gastroenterology 1994;106. doi:10.1016/0016-5085(94)90614-9.

[197] Schett G, Manger B, Simon D, Caporali R. COVID-19 revisiting inflammatory pathways of arthritis. Nat Rev Rheumatol 2020;16:465-470. doi:10.1038/s41584-020-0451-z.

[198] Schroder K, Tschopp J. The inflammasomes. Cell 2010;140. doi:10.1016/j.cell.2010.01.040.

[199] Seif F, Khoshmirsafa M, Aazami H, Mohsenzadegan M, Sedighi G, Bahar M. The role of JAK-STAT signaling pathway and its regulators in the fate of T helper cells. Cell Commun Signal 2017;15. doi:10.1186/s12964-017-0177-y.

[200] Shabab T, Khanabdali R, Moghadamtousi SZ, Kadir HA, Mohan G. Neuroinflammation pathways: a general review. International Journal of Neuroscience 2017;127:624-633. doi:10.1080/00207454.2016.1212854.

[201] Shimabukuro-Vornhagen A, Gödel P, Subklewe M, Stemmler HJ, Schlößer HA, Schlaak M, Kochanek M, Böll B, von Bergwelt-Baildon MS. Cytokine release syndrome. J Immunother Cancer 2018;6:56. doi:10.1186/s40425-018-0343-9.

[202] Silverman MN, Pearce BD, Biron CA, Miller AH. Immune Modulation of the Hypothalamic-Pituitary-Adrenal (HPA) Axis during Viral Infection. Viral Immunol 2005;18:41. doi:10.1089/vim.2005.18.41.

[203] Singh KK, Chaubey G, Chen JY, Suravajhala P. Decoding SARS-CoV-2 hijacking of host mitochondria in COVID-19 pathogenesis. Am J Physiol Cell Physiol 2020;319:C258-C267. 
doi:10.1152/ajpcell.00224.2020.

[204] Sinha P, Matthay MA, Calfee CS. Is a "Cytokine Storm" Relevant to COVID-19? JAMA Internal Medicine 2020;180:1152. doi:10.1001/jamainternmed.2020.3313.

[205] Somasundaram NP, Ranathunga I, Ratnasamy V, Wijewickrama PSA, Dissanayake HA, Yogendranathan N, Gamage KKK, de Silva NL, Sumanatilleke M, Katulanda P, Grossman AB. The Impact of SARS-Cov-2 Virus Infection on the Endocrine System. J Endocr Soc 2020;4. doi:10.1210/jendso/bvaa082.

[206] Soni S, Anand P, Padwad YS. MAPKAPK2: the master regulator of RNA-binding proteins modulates transcript stability and tumor progression. J Exp Clin Cancer Res 2019;38:1-18. doi:10.1186/s13046-019-1115-1.

[207] Son Y, Cheong Y-K, Kim N-H, Chung H-T, Kang DG, Pae H-O. Mitogen-Activated Protein Kinases and Reactive Oxygen Species: How Can ROS Activate MAPK Pathways? J Signal Transduct 2011;2011. doi:10.1155/2011/792639.

[208] Sorokowski P, Karwowski M, Misiak M, Marczak MK, Dziekan M, Hummel T, Sorokowska A. Sex Differences in Human Olfaction: A Meta-Analysis. Front Psychol 2019;10.

doi:10.3389/fpsyg.2019.00242.

[209] Sotzny F, Blanco J, Capelli E, Castro-Marrero J, Steiner S, Murovska M, Scheibenbogen C. Myalgic Encephalomyelitis/Chronic Fatigue Syndrome - Evidence for an autoimmune disease. Autoimmun Rev 2018;17. doi:10.1016/j.autrev.2018.01.009.

[210] Soukup K, Halfmann A, Le Bras M, Sahin E, Vittori S, Poyer F, Schuh C, Luger R, Niederreiter B, Haider T, Stoiber D, Blüml S, Schabbauer G, Kotlyarov A, Gaestel M, Felzmann T, Dohnal AM. The MAPK-Activated Kinase MK2 Attenuates Dendritic Cell-Mediated Th1 Differentiation and Autoimmune Encephalomyelitis. The Journal of Immunology 2015;195:541-552. doi:10.4049/jimmunol.1401663.

[211] Späth-Schwalbe E, Hansen K, Schmidt F, Schrezenmeier H, Marshall L, Burger K, Fehm HL, Born J. Acute Effects of Recombinant Human Interleukin-6 on Endocrine and Central Nervous Sleep Functions in Healthy Men 1. J Clin Endocrinol Metab 1998;83:1573-1579. doi:10.1210/jcem.83.5.4795.

[212] Steiner S, Becker SC, Hartwig J, Sotzny F, Lorenz S, Bauer S, Löbel M, Stittrich AB, Grabowski P, Scheibenbogen C. Autoimmunity-Related Risk Variants in PTPN22 and CTLA4 Are Associated With ME/CFS With Infectious Onset. Front Immunol 2020;11. doi:10.3389/fimmu.2020.00578.

[213] Streit WJ, Mrak RE, Griffin WST. Microglia and neuroinflammation: a pathological perspective. J Neuroinflammation 2004;1:1-4. doi:10.1186/1742-2094-1-14.

[214] Stringer EA, Baker KS, Carroll IR, Montoya JG, Chu L, Maecker HT, Younger JW. Daily cytokine fluctuations, driven by leptin, are associated with fatigue severity in chronic fatigue syndrome: evidence of inflammatory pathology. J Transl Med 2013;11:93. doi:10.1186/1479-5876-11-93.

[215] Sudhakar R. Subramaniam HJF. Targeting Microglial Activation States as a Therapeutic Avenue in 
Parkinson's Disease. Front Aging Neurosci 2017;9. doi:10.3389/fnagi.2017.00176.

[216] Sudre CH, Murray B, Varsavsky T, Graham MS, Penfold RS, Bowyer RC, Pujol JC, Klaser K, Antonelli M, Canas LS, Molteni E, Modat M, Jorge Cardoso M, May A, Ganesh S, Davies R, Nguyen LH, Drew DA, Astley CM, Joshi AD, Merino J, Tsereteli N, Fall T, Gomez MF, Duncan EL, Menni C, Williams FMK, Franks PW, Chan AT, Wolf J, Ourselin S, Spector T, Steves CJ. Attributes and predictors of Long-COVID: analysis of COVID cases and their symptoms collected by the Covid Symptoms Study App. medRxiv 2020:2020.10.19.20214494. doi:10.1101/2020.10.19.20214494.

[217] Suzuki K. Characterization of Exercise-Induced Cytokine Release, the Impacts on the Body, the Mechanisms and Modulations. n.d. doi:10.23937/2469-5718/1510122.

[218] Systematic interleukin-1 administration stimulates hypothalamic norepinephrine metabolism parallelling the increased plasma corticosterone. Life Sci 1988;43:429-435. doi:10.1016/0024-3205(88)90522-X.

[219] Tanase DM, Gosav EM, Radu S, Ouatu A, Rezus C, Ciocoiu M, Costea CF, Floria M. Arterial Hypertension and Interleukins: Potential Therapeutic Target or Future Diagnostic Marker? Int J Hypertens 2019;2019. doi:10.1155/2019/3159283.

[220] Taneja V. Sex Hormones Determine Immune Response. Front Immunol 2018;9. doi:10.3389/fimmu.2018.01931.

[221] Tan IL, Mowry EM, Steele SU, Pardo CA, McArthur JC, Nath A, Venkatesan A. Brainstem encephalitis: etiologies, treatment, and predictors of outcome. J Neurol 2013;260:2312. doi:10.1007/s00415-013-6986-z.

[222] Tay TL, Béchade C, D’Andrea I, St-Pierre M-K, Henry MS, Roumier A, Tremblay M-E. Microglia Gone Rogue: Impacts on Psychiatric Disorders across the Lifespan. Front Mol Neurosci 2018;10. doi:10.3389/fnmol.2017.00421.

[223] Tenforde MW, Kim SS, Lindsell CJ, Rose EB, Shapiro NI, Clark Files D, Gibbs KW, Erickson HL, Steingrub JS, Smithline HA, Gong MN, Aboodi MS, Exline MC, Henning DJ, Wilson JG, Khan A, Qadir N, Brown SM, Peltan ID, Rice TW, Hager DN, Ginde AA, Stubblefield WB, Patel MM, Self WH, Feldstein LR, Hart KW, McClellan R, Dorough L, Dzuris N, Griggs EP, Kassem AM, Marcet PL, Ogokeh CE, Sciarratta CN, Siddula A, Smith ER, Wu MJ, IVY Network Investigators, CDC COVID-19 Response Team, IVY Network Investigators, CDC COVID-19 Response Team. Symptom Duration and Risk Factors for Delayed Return to Usual Health Among Outpatients with COVID-19 in a Multistate Health Care Systems Network - United States, March-June 2020. MMWR Morbidity and Mortality Weekly Report 2020;69:993-998. doi:10.15585/mmwr.mm6930e1.

[224] The role of antioxidants in the chemistry of oxidative stress: A review. Eur J Med Chem 2015;97:55-74. doi:10.1016/j.ejmech.2015.04.040.

[225] Tisoncik JR, Korth MJ, Simmons CP, Farrar J, Martin TR, Katze MG. Into the eye of the cytokine storm. Microbiol Mol Biol Rev 2012;76:16-32. doi:10.1128/MMBR.05015-11.

[226] Tohidpour A, Morgun AV, Boitsova EB, Malinovskaya NA, Martynova GP, Khilazheva ED, Kopylevich NV, Gertsog GE, Salmina AB. Neuroinflammation and Infection: Molecular Mechanisms Associated with Dysfunction of Neurovascular Unit. Front Cell Infect Microbiol 2017;7. 
doi:10.3389/fcimb.2017.00276.

[227] Tripathi SK, Lahesmaa R. Transcriptional and epigenetic regulation of T-helper lineage specification. Immunol Rev 2014;261:62-83. doi:10.1111/imr.12204.

[228] Trivedi MS, Oltra E, Sarria L, Rose N, Beljanski V, Fletcher MA, Klimas NG, Nathanson L. Identification of Myalgic Encephalomyelitis/Chronic Fatigue Syndrome-associated DNA methylation patterns. PLoS One 2018;13. doi:10.1371/journal.pone.0201066.

[229] de Vega WC, Herrera S, Vernon SD, McGowan PO. Epigenetic modifications and glucocorticoid sensitivity in Myalgic Encephalomyelitis/Chronic Fatigue Syndrome (ME/CFS). BMC Med Genomics 2017;10:1-14. doi:10.1186/s12920-017-0248-3.

[230] Vollmer-Conna U, Piraino BF, Cameron B, Davenport T, Hickie I, Wakefield D, Lloyd AR, Dubbo Infection Outcomes Study Group. Cytokine polymorphisms have a synergistic effect on severity of the acute sickness response to infection. Clin Infect Dis 2008;47:1418-1425. doi:10.1086/592967.

[231] Wang X, Zheng J, Guo L, Yao H, Wang L, Xia X, Zhang W. Fecal viral shedding in COVID-19 patients: Clinical significance, viral load dynamics and survival analysis. Virus Res 2020;289:198147. doi:10.1016/j.virusres.2020.198147.

[232] Wan J-J, Qin Z, Wang P-Y, Sun Y, Liu X. Muscle fatigue: general understanding and treatment. Exp Mol Med 2017;49:e384. doi:10.1038/emm.2017.194.

[233] Welsh P, Woodward M, Rumley A, Lowe G. Associations of plasma pro-inflammatory cytokines, fibrinogen, viscosity and $\mathrm{C}$-reactive protein with cardiovascular risk factors and social deprivation: the fourth Glasgow MONICA study. Br J Haematol 2008;141:852-861. doi:10.1111/j.1365-2141.2008.07133.x.

[234] Wendling D, Racadot E, Wijdenes J. Treatment of severe rheumatoid arthritis by anti-interleukin 6 monoclonal antibody. J Rheumatol 1993;20. Available:

https://pubmed.ncbi.nlm.nih.gov/8474061/. Accessed 15 Aug 2020.

[235] Wichmann D, Sperhake JP, Lütgehetmann M, Steurer S, Edler C, Heinemann A, Heinrich F, Mushumba H, Kniep I, Schröder AS, Burdelski C, de Heer G, Nierhaus A, Frings D, Pfefferle S, Becker $H$, Bredereke-Wiedling $H$, de Weerth A, Paschen HR, Sheikhzadeh-Eggers S, Stang A, Schmiedel S, Bokemeyer C, Addo MM, Aepfelbacher M, Püschel K, Kluge S. Autopsy Findings and Venous Thromboembolism in Patients With COVID-19: A Prospective Cohort Study. Ann Intern Med 2020;173. doi:10.7326/M20-2003.

[236] Wu C, Chen X, Cai Y, Xia J'an, Zhou X, Xu S, Huang H, Zhang L, Zhou X, Du C, Zhang Y, Song J, Wang S, Chao Y, Yang Z, Xu J, Zhou X, Chen D, Xiong W, Xu L, Zhou F, Jiang J, Bai C, Zheng J, Song Y. Risk Factors Associated With Acute Respiratory Distress Syndrome and Death in Patients With Coronavirus Disease 2019 Pneumonia in Wuhan, China. JAMA Intern Med 2020. doi:10.1001/jamainternmed.2020.0994.

[237] Wu P, Duan F, Luo C, Liu Q, Qu X, Liang L, Wu K. Characteristics of Ocular Findings of Patients With Coronavirus Disease 2019 (COVID-19) in Hubei Province, China. JAMA Ophthalmol 2020;138:575. doi:10.1001/jamaophthalmol.2020.1291. 
[238] Wu Y, Guo C, Tang L, Hong Z, Zhou J, Dong X, Yin H, Xiao Q, Tang Y, Qu X, Kuang L, Fang X, Mishra $\mathrm{N}$, Lu J, Shan $\mathrm{H}$, Jiang $\mathrm{G}$, Huang $X$. Prolonged presence of SARS-CoV-2 viral RNA in faecal samples. Lancet Gastroenterol Hepatol 2020;5:434-435. doi:10.1016/S2468-1253(20)30083-2.

[239] Xiao J, Li J, Cai L, Chakrabarti S, Li X. Cytokines and Diabetes Research. Journal of Diabetes Research 2014;2014. doi:10.1155/2014/920613.

[240] Yamato M, Kataoka Y. Fatigue sensation following peripheral viral infection is triggered by neuroinflammation: who will answer these questions? Neural Regeneration Res 2015;10:203-204. doi:10.4103/1673-5374.152369.

[241] Yamato M, Tamura Y, Eguchi A, Kume S, Miyashige $Y$, Nakano M, Watanabe $Y$, Kataoka Y. Brain interleukin-1 $\beta$ and the intrinsic receptor antagonist control peripheral Toll-like receptor 3-mediated suppression of spontaneous activity in rats. PLoS One 2014;9:e90950. doi:10.1371/journal.pone.0090950.

[242] Yan CH, Faraji F, Prajapati DP, Ostrander BT, DeConde AS. Self-reported olfactory loss associates with outpatient clinical course in COVID-19. Int Forum Allergy Rhinol 2020;10. doi:10.1002/alr.22592.

[243] Yang Y, Shen C, Li J, Yuan J, Yang M, Wang F, Li G, Li Y, Xing L, Peng L, Wei J, Cao M, Zheng H, Wu W, Zou R, Li D, Xu Z, Wang H, Zhang M, Zhang Z, Liu L, Liu Y. Exuberant elevation of IP-10, MCP-3 and IL-1ra during SARS-CoV-2 infection is associated with disease severity and fatal outcome. medRxiv 2020:2020.03.02.20029975. doi:10.1101/2020.03.02.20029975.

[244] Yasmin R, Siraj S, Hassan A, Khan AR, Abbasi R, Ahmad N. Epigenetic Regulation of Inflammatory Cytokines and Associated Genes in Human Malignancies. Mediators Inflamm 2015;2015. doi:10.1155/2015/201703.

[245] Ye Q, Wang B, Mao J. The pathogenesis and treatment of the 'Cytokine Storm' in COVID-19. Journal of Infection 2020;80:607-613. doi:10.1016/j.jinf.2020.03.037.

[246] Yirmiya R, Pollak Y, Morag M, Reichenberg A, Barak O, Avitsur R, Shavit Y, Ovadia H, Weidenfeld J, Morag A, Newman ME, Pollmächer T. Illness, Cytokines, and Depression. Annals of the New York Academy of Sciences 2006;917:478-487. doi:10.1111/j.1749-6632.2000.tb05412.x.

[247] Yucesoy B, Kashon ML, Luster MI. Cytokine polymorphisms in chronic inflammatory diseases with reference to occupational diseases. Curr Mol Med 2003;3. doi:10.2174/1566524033361582.

[248] Zhang P, Li J, Liu H, Han N, Ju J, Kou Y, Chen L, Jiang M, Pan F, Zheng Y, Gao Z, Jiang B. Long-term bone and lung consequences associated with hospital-acquired severe acute respiratory syndrome: a 15-year follow-up from a prospective cohort study. Bone research 2020;8. doi:10.1038/s41413-020-0084-5.

[249] Zhang S, Liu Y, Wang X, Yang L, Li H, Wang Y, Liu M, Zhao X, Xie Y, Yang Y, Zhang S, Fan Z, Dong J, Yuan Z, Ding Z, Zhang Y, Hu L. SARS-CoV-2 binds platelet ACE2 to enhance thrombosis in COVID-19. J Hematol Oncol 2020;13:1-22. doi:10.1186/s13045-020-00954-7.

[250] Zheng HY, Zhang M, Yang CX, Zhang N, Wang XC, Yang XP, Dong XQ, Zheng YT. Elevated exhaustion levels and reduced functional diversity of $T$ cells in peripheral blood may predict severe 
progression in COVID-19 patients. Cell Mol Immunol 2020;17. doi:10.1038/s41423-020-0401-3.

[251] Zheng ZV, Wong KCG. Microglial activation and polarization after subarachnoid hemorrhage. Neuroimmunology and Neuroinflammation 2019;6. doi:10.20517/2347-8659.2018.52. 


\section{Figure Legends}

Figure 1. Grading of the Cytokine Release Syndrome. Activation of T cells induces a release of IFN- $\gamma$ or TNF- $\alpha$. This process activates macrophages and other immune cells, releasing proinflammatory cytokines. Large amounts of IL-6 are released, which in a positive feedback loop activates $T$ cells and other immune cells leading to a cytokine storm. CRS Shimabukuro-Vornhagen (http://creativecommons.org/licenses/by/4.0/)

Figure 2. Proposed model of pathophysiology underlying CNS-mediated Long COVID symptoms.

Figure 3. Schematic of microglial polarization states and functions. [215] (http://creativecommons.org/licenses/by/4.0/)

Figure 4. SARS-CoV-2 induces overwhelming inflammation by directly activating p38 and downregulating the Ang1-7 inhibitory pathway [92].

(http://creativecommons.org/licenses/by/4.0/)

Figure 5. Epigenetic mechanisms altering gene expression. Scientific Illustration of How Epigenetic Mechanisms Can Affect Health National Institutes of Health (http://creativecommons.org/licenses/by/4.0/)

Figure 6. Potential pathomechanism of ME/CFS. Dysregulation of the immune system, autonomic nervous system (ANS) and metabolic disturbances contribute to this complex syndrome. In most patients, disease onset is triggered by infection with stress, immunodeficiency and autoimmunity as known risk factors [209] (http://creativecommons.org/licenses/by/4.0/)

Figure 7. Molecular mechanism of transient fever and suppression of locomotor activity (fatigue) following viral infection [240]. IL-1ra prevents shift from acute to chronic inflammatory state. $x$ 